\title{
NGOs and Legitimacy in International Development
}

\author{
Sophie Smyth*
}

\section{INTRODUCTION}

The end of the Cold War melted the bipolar world that arranged most every international policy in terms of West and East. Once freed from this aspic, nongovernmental organizations (NGOs) emerged on the world stage with new power and stature to shape agendas in international development. These changes have altered the face of international development assistance and presented new challenges for the design of new international development institutions and the continued relevance of the old.

This Article takes up those challenges and, in doing so, fills a gap in two distinct but related bodies of scholarship. The post-Cold War growth of NGOs and their proper role in public international affairs has been the subject of a robust literature in legal scholarship. ${ }^{1}$ The impact of globalization on international development is also extensively discussed in scholarship on development economics and global justice. ${ }^{2}$

\footnotetext{
Associate Professor of Law, Beasley School of Law, Temple University. This Article has benefited greatly from the inputs of participants in the symposium Governing Civil Society: NGO Accountability, Legitimacy and Influence held at Brooklyn Law School in October 2010 and from the University of Richmond School of Law faculty, to whom I presented an early draft. Thanks are also due to Peter Spiro, Amy Sinden, Richard Greenstein, and Katherine Jones for very helpful insights on early drafts, and to David Fagelson for much useful guidance. I am also grateful for the excellent research assistance of Noa Kaumeheiwa, Timothy O’Carroll, Benjamin Vaughan, Kalina Lovell, Peter Veloski, Jane Osterlind, Amy Drapkin, and Erica Dressler.

1. See, e.g., Kenneth Anderson \& David Rieff, 'Global Civil Society': A Sceptical View, in GlobAl Civil SociETY 26 (Helmut Anheier et al. eds., 2005); Steve Charnovitz, The Illegitimacy of Preventing NGO Participation, 36 BRoOK. J. INT'L L. 891 (2011); Peter J. Spiro, Accounting for NGOs, 3 CHI. J. INT'L L. 161 (2002); Kal Raustiala, Note, The “Participatory Revolution” in International Environmental Law, 21 HARV. ENVTL. L. REV. 537 (1997).

2. See, e.g., JEFFrey SACHS, THE END OF POVERTY: ECONOMIC POSSIBILITIES FOR OUR Time (2005); Joseph E. STiglitz, Globalization AND ITS DiscontenTS (2003); Deen K. Chatterjee, Introduction to The Ethics of Assistance: Morality AND the Distant NeEDY 1 (Deen K. Chatterjee ed., 2004); Thomas W. Pogge, "Assisting" the Global Poor, in The ETHICs OF AsSistanCE: MoRAlity AND THE Distant NEEDY, supra, at 260. For the purposes of this Article, I take "globalization" to connote an increased interdependence and interaction among countries and
} 
I examine how these phenomena combine to affect international development institutions.

The challenges for the design of international development institutions that arise because of NGOs' expanded power concern what priorities get to control. Since the end of the Cold War, the priorities of cause NGOs such as WorldVision, Oxfam, Save the Children, and many others with expertise in development have replaced the Cold War priorities of donor countries as the driving force in setting development aid agendas. ${ }^{3}$ These NGOs have a deep and abiding interest in the humanitarian needs of developing country citizens. As their priorities become donor country priorities, the priorities of the development institutions that donor countries create change also. ${ }^{4}$ So too, do the kinds of information and inputs those institutions need to fulfill the tasks expected of them. In particular, information about the needs, views, and lives of ordinary citizens becomes key. This is the kind of information and expertise NGOs are seen as uniquely qualified to provide given their extensive experience in the field. ${ }^{5}$

NGOs, claiming to have this expertise, have fought hard in recent years for the right to participate in the governance of international development institutions. ${ }^{6}$ Their efforts have met with considerable success. For example, many NGOs now participate, along with

their citizens - both as between developed and developing countries, and between developed countries inter se- that began with the end of the Cold War and the subsequent rise in opportunities for greater transnational activity. See Tim Dunne, The Spectre of Globalization, 7 IND. J. GLOBAL LEGAL STUD. 17, 20-21 (1999) (discussing a widely-used definition of globalization incorporating "the intensification of worldwide social relations" (quoting Anthony Giddens, quoted in Jan Hart Scholte, The Globalization of World Politics, in THE Globalization OF WORLD POLiTiCs 14, 15 (John Baylis \& Steve Smith eds., 1997)) (internal quotation marks omitted)).

3. See, e.g., David Lewis, Development NGOs and the Challenge of Partnership: Changing Relations Between North and South, 32 Soc. POL'Y \& ADMIN. 501, 502-03 (1998) (discussing NGOs' increased prominence and the changes in development policy beginning in the 1990s).

4. See Devesh Kapur, The Changing Anatomy of Governance of the World Bank, in REINVENTING THE WORLD BANK 54, 63 (Jonathan R. Pincus \& Jeffrey A. Winters eds., 2002) (noting how donor countries influence the World Bank and how donor countries themselves are influenced by lobbying NGOs).

5. See Debora Spar \& James Dail, Of Measurement and Mission: Accounting for Performance in Non-Governmental Organizations, 3 CHI. J. INT'L L. 171, 172 (2002) (noting that NGOs are "major conduits for development aid" and in some countries perform services ordinarily handled by local government).

6. For the purposes of this Article, I adopt Barbara Koremenos's, Charles Lipson's, and Duncan Snidal's definition of international institution: “[an] explicit arrangement[], negotiated among international actors, that prescribe[s], proscribe[s], and/or authorize[s] behavior." Barbara Koremenos, Charles Lipson \& Duncan Snidal, The Rational Design of International Institutions, in The Rational Design of International Institutions 1, 2 (Barbara Koremenos et al. eds., 2003). 
governments, in the governance of the newest international development institutions, such as The Global Fund to Fight AIDS, Tuberculosis and Malaria (Global Fund) ${ }^{7}$ and the Global Environment Facility (GEF). ${ }^{8}$ Participating NGOs range from well-known large international organizations like the World Wildlife Fund to local organizations such as southern Africa's ZERO Regional Environment Organization. ${ }^{9}$ Having broken a traditional barrier between private and governmental organizations, NGOs now maintain that their participation in institutional governance is critical to any development institution's legitimacy.

Recently, for example, commentators have argued that NGO participation in governance is a condition of the newly minted Green Climate Fund's legitimacy. ${ }^{10}$ In response to similar arguments, the Education for All-Fast Track Initiative (now the Global Partnership for Education) fund, a global fund for primary school education in developing countries, recently restructured to allow NGOs to participate in governance. ${ }^{11}$ Prominent policymakers have also suggested that NGO participation in governance is necessary for the legitimacy of other international development institutions. For example, former World Bank $^{12}$ President Jim Wolfensohn pushed the Bank to be more inclusive

7. See Cheryl TOKSOZ, The Global Fund to Fight AIDS, TUbERCUlosis AND MALARIA, PARtNering for Global HeAlth: The Global Fund AND the Private Sector 28 (2010), available at http://www.theglobalfund.org/en/about/donors/private/ (follow "Partnering for Global Health with the Private Sector (PDF-2MB)" hyperlink) (listing private sector board members and contributors).

8. See Global Env't Facility [GEF], Enhancing the Engagement of Civil Society Organizations in the Operations of the GEF, at iii, GEF/C.39/10/Rev.1 (Nov. 18, 2010), available at http://www.thegef.org/gef/GEF_C.39_10_Rev.1_Enhancing_the_Engagement_of_CSO (noting that NGOs have historically participated in governance of the GEF).

9. See, e.g., Members, GEF-NGO NETWORK, http://www.gefngo.org/formmaster.cfm?\& action=main\&menuid=12 (last visited Sept. 15, 2012).

10. See, e.g., Katherine Sierra, Brookings Inst., The Green Climate Fund's Private SECTOR FACILITY: THE CASE FOR PRIVATE SECTOR PARTICIPATION ON THE BOARD 3 (2012), available at http://www.brookings.edu/research/papers/2012/08/green-climate-private-sector-sierra (summarizing arguments for private sector participation on the board of the Green Climate Fund).

11. See The Educ. FOR All-Fast Track Initiative, 2010 AnNuAl Report 4 (2011), available at http://www.globalpartnership.org/library/publications/.

12. As used herein, the term "World Bank" or "Bank" refers collectively to two distinct legal entities within the World Bank Group: the International Bank for Reconstruction and Development (IBRD) and the International Development Association (IDA). IBRD uses the proceeds of its bond issues to issue loans to developing countries. INT'L BANK FOR RECONSTRUCTION \& DEV., INFORMATION STATEMENT 26 (Sept. 9, 2012), http://treasury.worldbank.org/cmd/pdf/Information Statement.pdf [hereinafter WORLD BANK, INFORMATION STATEMENT]. IDA is funded mainly by contributions from member countries, which are replenished every three years. IDA Replenishments, WORLD BANK, http://www.worldbank.org/ida/ida-replenishments.html (last visited Sept. 15, 2012). IDA issues low-interest or interest-free loans and some grants to developing countries. What is IDA?, WORLD BANK, http://www.worldbank.org/ida/what-is-ida.html (last visited Sept. 15, 2012). 
of NGOs. ${ }^{13}$ Another former Bank president, Robert Zoellick, has also noted that organizations like the Bank should connect "more and more countries, companies, individuals, and NGOs" to be an effective and legitimate institution. ${ }^{14}$ In a similar vein, then-Secretary-General of the United Nations (UN), Kofi Annan, declared in 2001 that increased engagement of civil society organizations in the UN's proposed "Global Fund" to fight infectious disease would be integral to its success. ${ }^{15}$

If these claims are valid, and NGO participation in governance is indeed critical to the legitimacy of an international development institution, ${ }^{16}$ the implications are far-reaching. It would mean that the design of all new state-sponsored development initiatives should include NGO participation in their governance structures. It would also prompt reevaluation of the legitimacy of existing development institutions, such as the World Bank and the United Nations Development Program (UNDP), from whose governance NGOs are presently excluded. This Article examines these implications in three stages. First, it analyzes what proponents of NGO participation in governance appear to mean when they claim that NGO participation is critical to institutional legitimacy. Second, it explores the underlying values and goals at stake. Lastly, it reviews what evidence we have that the claim can be supported.

The first stage shows that legitimacy is the wrong frame within which to evaluate what NGO participation in governance contributes to

13. Sebastian Mallaby, Columnist, Wash. Post, Debate Sponsored by the Robert F. Kennedy Center for Human Rights: Protagonists or Antagonists? The Role of NGOs and the World Bank in the Fight Against Poverty (Nov. 18, 2004), available at rfkcenter.org/protagonists-or-antagoniststhe-role-of-ngos-and-the-world-bank-in-the-fight-against-poverty.

14. See Robert B. Zoellick, The End of the Third World? Modernizing Multilateralism for a Multipolar World, 16 L. \& BUS. REV. AM. 371, 381 (2010) ("Modern multilateralism will not be a constricted club with more left outside the room than seated within.... Legitimate and effective multilateral institutions, backed by resources and capable of delivering results, can form an interconnecting tissue, reaching across the skeletal architecture of this dynamic, multipolar system.”); see also Ramesh Jaura, The Brave New World of Robert Zoellick, GLOBAL GEOPOLITICS \& POL. ECON. (Apr. 22, 2010), http://globalgeopolitics.net/wordpress/2010/04/23/the-brave-newworld-of-robert-zoellick/.

15. See Press Release, Secretary-General Kofi Annan, Secretary-General Proposes Global Fund for Fight Against HIV/AIDS and Other Infectious Diseases at African Leaders Summit, U.N. Press Release SG/SM/7779/Rev.1 (Apr. 26, 2001) [hereinafter Annan Press Release] (discussing civil society's role in developing and implementing the ideas proposed by the Secretary-General); see also G.A. Res. S-26/2, ๆๆ 32, 90, U.N. Doc. A/RES/S-26/2 (Aug. 2, 2001) (noting governments' efforts in combating HIV/AIDS should be complemented by the active participation of civil society).

16. The legitimacy of international institutions is important for at least two reasons. First, it may be important to know whether an institution deserves support. Daniel Bodansky, Legitimacy in International Law and International Relations 7 (Jan. 26, 2012) (unpublished manuscript), available at http://ssrn.com/abstract=1900289. Second, a legitimate institution may be perceived as "more likely to be effective or stable.” Id. 
an international development institution. The capacity of NGOs to contribute to institutional credibility is a more fruitful inquiry. These concepts are not synonymous. Legitimacy is about authority, and includes a moral component that justifies the state's monopoly of power. ${ }^{17}$ Credibility is a distinct concept that, as applied to an international development institution, relates to our trust in the institution's commitment and ability to set terms and conditions of assistance that will advance development. Arguments in support of NGO participation incorrectly conflate legitimacy and credibility. The authority of an institution, like the World Bank or the Global Fund, to set the terms and conditions of a loan or grant, i.e., the institution's legitimacy, is not in doubt, regardless of whether its governance structure includes NGOs. Development institutions are international Weberian bureaucracies. ${ }^{18}$ Their legitimacy depends on their complying with the preordained mandates of the states that created them; it is derivative from the legitimacy of their member states. What is in doubt, however, is their credibility: the ability of institutions, like the World Bank, that exclude NGOs from governance to properly calibrate the terms and conditions of assistance to achieve the goals we support.

Having shown why NGOs' role is not a legitimating one, the Article then examines their potential to contribute to institutional credibility. ${ }^{19}$

17. See Daniel Bodansky, The Legitimacy of International Governance: A Coming Challenge for International Environmental Law?, 93 AM. J. INT’L L. 596, 600-01, 601 n.29 (1999) (explaining how "'legitimacy' refers to the justification of authority" and listing a definition of legitimacy where moral goodness serves as a justification (citing ROBERT A. DAHL, MODERN POLITICAL ANALYSIS 41 (2d ed. 1970))).

18. See infra Part II.D. Weberian bureaucracies are formal institutions with a "hierarchical authority structure," "specialized administrative staff," "limited objectives," different "rewards" according to office, and "segmental participation." Stanley H. Udy, Jr., "Bureaucracy" and "Rationality” in Weber's Organization Theory: An Empirical Study, 24 AM. Soc. REV. 791, 792-93 (1959) (italics omitted).

19. Paradoxically, if NGO participation contributes to increased institutional credibility, this ultimately could also contribute to institutional legitimacy. This is so because the legitimacy of an implementing bureaucratic organization partly depends on its ability to carry out its assigned tasks. Development institutions are technocratic expert organizations, not representative bodies. See Jonathan R. Pincus \& Jeffrey A. Winters, Reinventing the World Bank, in REINVENTING THE WORLD BANK, supra note 4, at 20 (arguing that the notion of the World Bank as a representative body that "speaks for the poor, the oppressed, and the nationally disenfranchised" is misguided because the Bank is at heart a development bank, which is a "membership, not a representative organization"); see also Kapur, supra note 4, at 75 ("An unpleasant reality of international institutions is that... they will not be democratic in the sense of democracy as a system of popular control over decision making." (citation omitted) (citing Robert A. Dahl, Can International Organizations Be Democratic? A Skeptic's View, in DEMOCRACY's EDGES 19 (Ian Shapiro \& Casiano Hacker-Cordón eds., 1999))). To the extent that NGOs enhance these institutions' expertise, they may augment these institutions' legitimacy. Any such augmentation of an institution's legitimacy, however, 
The second stage of the analysis addresses why and how NGOs may contribute to credibility and the stakes of advocating for greater NGO participation. I show that credibility is linked to perceptions of effectiveness. Those who advocate for NGO participation in governance maintain that NGO participation makes a development institution more effective and, therefore, more credible. $^{20}$ The contested nature of credibility and effectiveness in international development make it difficult to determine the contribution of NGOs. Citizens and the governments of donor and developing countries, as well as external watchdogs like NGOs, have differing views about what is legitimate and, therefore, also what is credible and effective. ${ }^{21}$ This Article focuses on credibility from the perspective of donor countries because such credibility is crucial to institutional survival: at any time donors can turn off the spigot. ${ }^{22}$ Donors are also the ones that determine whether NGOs

would result from the expertise the NGOs contribute, not from any notion of democratic representation. Whether NGOs actually have the requisite expertise and whether their participation augments the ability of international development institutions to achieve their goals are empirical questions that this Article can only frame. In clarifying the terms of engagement, however, I avoid looking to the wrong kind of data, i.e., the extent to which an international development institution is representative, to determine legitimacy.

20. See, e.g., Allison Bleaney \& CAROle Saint-Laurent, InT'L UNiON FOR THE CONSERVATION OF NATURE, REVIEW OF PRACTICES ON NGO/CSO PARTICIPATION AND

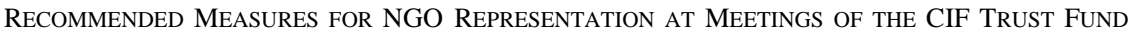
COMmitteEs 4-5 (Jan. 2009), in Climate Inv. Funds, Review of Practices on NGO/CSO Participation and Proposal for the CIF Committees, SCF/TFC.2/Inf.2, CTF/TFC.2/Inf.2 (Jan. 16, 2009), http://www.climateinvestmentfunds.org/cif/sites/climateinvestmentfunds.org/files/Review_of _Practices_NGO-CSO_Participation_Final_0.pdf; Annan Press Release, supra note 15; Zoellick, supra note 14, at 381; see also Charnovitz, supra note 1, at 893-95 (noting how NGOs benefit the international system and arguing that NGOs "correct for the pathologies of governments and [international organizations]").

21. See Bodansky, supra note 16, at 8 (noting that concepts of legitimacy are influenced by time, place, and people's beliefs).

22. This focus is not intended to diminish the importance of credibility in the eyes of borrowing and recipient countries. There is ample evidence, for example, that development projects are more effective where there is strong developing country buy-in. See, e.g., Lewis, supra note 3, at 506 (describing NGOs created in developing countries by developing country citizens as "increasingly effective"). But it is not an even playing field. Developing countries' need for finance likely causes many of them to accept the terms and conditions of assistance regardless of their views on the effectiveness of the end goal. The bottom line is that money flowing into a government's coffers usually helps keep that government in power. Dambisa Moyo, Why Foreign Aid is Hurting Africa, WALL ST. J., Mar. 21, 2009, http://online.wsj.com/article/SB123758895999200083.html. There may also be a wide disparity between credibility in the eyes of a developing country government and credibility in the eyes of the people who live under that government's domain. NGO participation is primarily viewed as increasing institutional credibility when the development goal to be achieved requires knowledge of and experience with the grassroots level. See David Gartner, Beyond the Monopoly of States, 32 U. PA. J. INT’L L. 595, 624-25 (2011) (discussing the ability of NGOs to connect with local stakeholders). However, the participation of NGOs in an institution may in some cases engender hostility in recipient governments. See Garry W. Jenkins, 
are given a role in institutional decision-making. What is at stake, however, is far more significant than institutional survival.

At a fundamental level, what is at stake is the compatibility of international development assistance priorities with norms and ideas of global justice. ${ }^{23}$ Development institutions' decisions have an enormous impact on the lives and wellbeing of developing country citizens. This is especially true in countries where development assistance forms a significant part of the public budget. For example, a country may be required to revamp its tax policy to receive a World Bank development policy loan. ${ }^{24}$ Alternatively, a country may need to eliminate logging from swaths of territory to qualify for a GEF grant, resulting in a major upheaval for those whose livelihoods depend on logging. ${ }^{25}$ The impact of requirements like these will be felt whether or not the international development institution is credible or effective. Proponents of NGO participation, however, maintain that NGOs' participation increases the likelihood that an institution's policies, operations, and practices will be sensitive to the needs of affected developing country citizens. ${ }^{26}$ NGOs add value to development initiatives because it is perceived that they can, will, and have "asked the turtle."27 Implicit in this argument is the view

Nongovernmental Organizations and the Forces Against Them: Lessons of the Anti-NGO Movement, 37 BROOK. J. INT’L L. 459, 482 (2012). Frequently, the value of NGO participation is precisely their ability to provide input about the needs of a developing country's citizens that its government would prefer to ignore. See id. (noting the fraught relationship between some developing countries' governments and human rights and environmental NGOs).

23. See generally Erin Kelly, Human Rights as Foreign Policy Imperatives, in THE ETHICs of AssistanCE: Morality AND THE Distant NEEDY, supra note 2, at 177 (discussing the interaction of principles of global justice and international development assistance); Richard W. Miller, Moral Closeness and World Community, in The Ethics of Assistance: MORAlity AND the Distant NEEDY, supra note 2, at 101 (same).

24. See, e.g., The World Bank, International Bank for Reconstruction and Development Program Document for a Third Development Policy Loan in the Amount of $€ 400$ Million (US\$ 560.6 Million Equivalent) to Romania, at 9-10, Report No. 64772-RO (Nov. 20, 2011).

25. See, e.g., The World Bank, Global Environment Facility Trust Fund Grant Agreement (Amazon Region Protected Areas Project) Between Fundo Brasileiro Para a BiodiversidadeFUNBIO and International Bank for Reconstruction and Development, at 39, GEF Trust Fund Grant No. TF051240 (Oct. 24, 2002).

26. See infra Part III.A.

27. See Donna Brazile, Donna Brazile Shares the Best Advice She Ever Got, OPRAH. COM (June 2010), http://www.oprah.com/money/Donna-Braziles-Rules-to-Live-By-the-SmartestAdvice-She-Got. On a field trip as a geology student, Gloria Steinem came across a large snapping turtle in an embankment at the side of a road by a river. Id. Assuming that the turtle was about to cross the road and worried that it would get crushed by a car, Steinem picked it up and carried it back to the river. Id. When she told her professor about the incident, he pointed out that the turtle likely spent at least a month climbing up to the embankment from the river to lay its eggs in the mud there. Id. Chagrined, Steinem recounted the incident to Donna Brazile to illustrate the important lesson of first asking others what kind of aid they need before rushing in with the aid we assume 
that fairness demands us to ensure that the terms and conditions of development assistance that our development institutions impose are congruent with achieving goals we support. ${ }^{28}$ Absent such congruence, the huge impact of development assistance on local populations is unjustifiable.

The third stage reviews evidence that NGO participation in governance enhances a development institution's credibility and examines the conditions that must be satisfied to maximize the likelihood that participation will have that effect. We need objective empirical research to determine the first aspect, but such research has not been done. $^{29}$ Drawing on case studies of recent practice, however, we can make some overall observations. First, as NGOs have become opinion leaders for international development assistance, they have mobilized public support and pushed international institutions to act. ${ }^{30}$ They condition their support, however, on their being allowed to participate in the governance of the institutions they urge governments to create. ${ }^{31}$ Simply put, for an institution to have credibility in the eyes of NGOs, NGOs must participate in the institution's governance. Given these power dynamics, NGO participation in governance in new international development institutions has become the norm. ${ }^{32}$ Secondly, it appears that the potential of NGO participation to contribute to credibility is strengthened by institutions' investment of significant resources to devise systems for selecting and monitoring NGOs. ${ }^{33}$ These systems help address concerns about NGO accountability and conflict of interest, which were obstacles to NGO participation in the past. ${ }^{34}$ Thirdly,

they need. See id.

28. See Pogge, supra note 2, at 276-77 (arguing that to the extent that institutions like the World Trade Organization, the IMF, and the World Bank knowingly or unwittingly pursue policies that hurt the global poor, they are part of a global order that is unjust).

29. As noted by David Gartner in Beyond the Monopoly of States, supra note 22, at 627 n.129, the Global Fund has published a report that maintains, or suggests, that the extensive NGO participation for which it provides has enhanced its results. However, we need an independent view.

30. See Pincus \& Winters, supra note 19, at 18-20 (noting that NGO protests against the World Bank have led the Bank to undertake many initiatives, a response that Pincus and Winters maintain has resulted in the Bank's loss of focus).

31. See, e.g., SIERRA, supra note 10, at 3 (arguing for private sector participation on the Green Climate Fund's board).

32. See id. at 6-7 (noting that the private sector increasingly participates in the governance of public pooled funds, and listing examples).

33. See Dana Brakman Reiser \& Claire R. Kelly, Linking NGO Accountability and the Legitimacy of Global Governance, 36 BROOK. J. INT'L L. 1011, 1054-63 (2011) (discussing accreditation approaches of various international organizations).

34. See id. at 1020 (noting that lack of a clear goal, poor governance, and managers interested only in their own benefit make NGO participation less appealing to international organizations). 
participation is not one size fits all. Competing models of NGO participation coexist without apparent damage to credibility. ${ }^{35}$ Moreover, the scope of NGO participation can be dynamic as an institution grows and shifts. ${ }^{36}$

Lastly, the new norm of NGO inclusion clearly has implications for the credibility of institutions that exclude NGOs from governance. Tired of hitting institutional glass ceilings in the World Bank and the UN, NGOs have urged donors to build new sandboxes in which to play in the form of autonomous special purpose funds. ${ }^{37}$ As a result, in recent years, most major new multilateral development initiatives have involved creating new special purpose funds. ${ }^{38}$ This proliferation of new institutions is costly in many ways. ${ }^{39}$ These costs warrant considering whether opening up the governance of the World Bank and the UN to NGO participation in some way might allow for a better consolidation of resources and thereby reduce the inclination towards institutional proliferation.

This Article's examination of these issues proceeds as follows. Part II defines key terms and analyzes the legitimacy of an international development institution. It shows that the claim that NGO participation in institutional governance is critical to institutional legitimacy misstates the case for NGO participation. The case for increased NGO participation in governance is really based on how NGO participation can aid credibility. Part III.A reviews current legal scholarship on the contribution of NGOs to international institutions. It shows how this scholarship supports the view that NGO participation in institutional governance has the potential to contribute significantly to a development institution's credibility. Part III.B reviews case studies of NGOs' participation in governance. Part III.C reviews inferences drawn from recent scholarship and practice about what NGO participation in

35. See id. at 1059-65 (describing different ways in which NGOs may participate in international organizations).

36. See id. at 1020 (discussing how NGOs and international institutions constantly evolve and change).

37. See Sophie Smyth, Collective Action for Development Finance, 32 U. PA. J. INT'L L. 961, 966 (2011).

38. See id. (listing examples of recently created special purpose funds).

39. See, e.g., id. at 969 (stating that gaps in governance and accountability in newly created funds, as well as political and legal uncertainty, create costs for international aid); see also Sebastian Mallaby, Saving the World Bank, ForEIGN AFF., May/June 2005, at 75, 75 (noting the creation of new funds and the disinterest in maintenance of existing institutions). 
governance contributes to the credibility of an international development institution. Part IV concludes.

\section{LEGITIMACY AND NGOS}

\section{A. Terms and Concepts}

The claim that participation of NGOs possessing relevant expertise and experience in an institution's governance is critical to the institution's legitimacy initially begs several questions about the definition of terms. What do we mean by "NGO," "participation," and "legitimacy," and what exactly is "relevant experience and expertise?"

\section{NGO}

"NGO" is a broad and elusive term. As Anna-Karin Lindblom points out, there is a wide spectrum of definitions of the term that vary according to the circumstances of its use. ${ }^{40}$ "Each institution has its own definition elaborated for its own purposes."41 Lindblom, however, identifies four elements of an NGO that apply across the range of existing definitions in international law. An NGO is: (a) autonomous from the state; ${ }^{42}$ (b) not-for-profit, which Lindblom defines as requiring that the entity "do[es] not have the primary aim of making a profit"; ${ }^{43}$ (c) not connected to violence or crime; ${ }^{44}$ and (d) an organization, meaning that it has "the capacity ... to act in its own name within [a national and] international legal context." "45 The definition of the term "NGO" found in international development includes these components but generally excludes political parties. ${ }^{46}$

The idea of including NGOs in any capacity in the work of international development institutions has always proceeded on the

40. See ANNA-KARIN LINDBLOM, NON-GOVERNMENTAL ORGANISATIONS IN INTERNATIONAL LAW 36 (2005) (explaining that "each area of law that relates to NGOs establishes its own definition” for the term).

41. Id. at 44.

42. Id. at $46-47$.

43. Id. at 48 (quoting COUNCIL OF EUROPE, FundAMENTAL PRINCIPLES ON THE STATUS OF NON-GOVERNMENTAL ORGANISATIONS IN EUROPE AND EXPLANATORY MEMORANDUM para. 4 (Nov. 13, 2002), http://www.coe.int/t/dghl/standardsetting/cdcj/ONG/Fundamental\%20Principles\% 20E.pdf) (internal quotation marks omitted).
44. Id. at 49.
45. Id. at 50 (emphasis omitted).
46. Id. at 48. 
assumption that only those with relevant expertise and experience will be considered. This principle is clearly evident, for example, in Article 71 of the UN Charter, the provision that controls UN development agencies' engagement with NGOs. Article 71 provides that the Economic and Social Council (ECOSOC), the body that oversees all of the UN's development activities, under the authority of the General Assembly, may "make suitable arrangements for consultation with nongovernmental organizations which are concerned with matters within its competence." ${ }^{47}$

The arrangements ECOSOC drafted pursuant to Article 71 reflect the principle that the level of an NGO's participation should vary according to the nature of the NGO. In short, the tighter the fit between ECOSOC and an NGO's objectives, the greater the participation allowed, subject, however, to certain immovable limits. ${ }^{48}$ Similarly, the GEF's criteria for NGO eligibility in the GEF-NGO Network (the vehicle for NGO involvement in the GEF) require that the NGO "specifically include environment protection and sustainable use as one of its important objectives." 49 The criteria also require that an NGO have a "proven track record of addressing environmental management issues relevant to one or more focal areas of the GEF for three or more years."50

As for what kind of expertise is relevant in development, NGOs' expected contribution is closely, although not exclusively, tied to the fact that NGOs have affiliations with and exposure to the grassroots levels of developing country citizens. NGOs are seen as having unique and needed expertise because they are extensively involved in the delivery of

\footnotetext{
47. U.N. Charter art. 71 (emphasis added).

48. See Steve Charnovitz, Two Centuries of Participation: NGOs and International Governance, 18 MiCH. J. INT'L L. 183, 252-53 (1997). ECOSOC's original arrangements established two categories of NGOs. Category A NGOs were "those with a basic interest in most of the activities of [ECOSOC]." Id. at 253. Category B NGOs were "those interested in some aspects of [ECOSOC's] work." Id. NGOs' consultative status varies according to how they are categorized. See E.S.C. Res. 1968/1296, ๆף 15-19, U.N. Doc. E/RES/1968/1296 (May 23, 1968). The ECOSOC arrangements also reflect the principle that NGO participation in ECOSOC's work would not mean participation in all aspects of ECOSOC's work. See id. ๆף 20-22 (noting specified activities organizations could participate in). All NGOs were excluded from some of ECOSOC's activities. For example, although some of ECOSOC's work is done through functional and regional commissions, Margaret P. Karns \& Karen A. MingSt, International Organizations: The Politics AND PROCESSES OF Global GOVERNANCE 116-17 (2004), ECOSOC decided against allowing NGO participation in its commissions at that time. Charnovitz, supra, at 253.

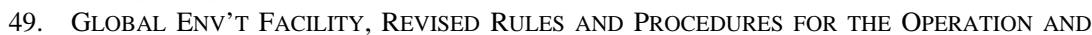
MANAGEMENT OF THE GEF-NGO NETWORK 32 (vers. 1.2 2010) [hereinafter GEF-NGO NETWORK REVISED RULES], available at http://gefngo.org/index.cfm?\&menuid=154.

50. Id.
} 
international development aid and the implementation of aid-funded projects. $^{51}$ The World Bank, for example, publicly acknowledges that NGO strengths commonly include "social proximity (grassroots and community links),... field-based development expertise,... [and] important specialized knowledge or skills." 52 The Bank also acknowledges the importance of NGOs' role in offering "grassroots insights and [in] challeng[ing] conventional development thinking., 53

The GEF and Global Fund's reliance on NGOs for local expertise is apparent in their requirements that a certain number of the NGO representatives who participate in those funds be drawn from local NGOs. ${ }^{54}$ Indeed, the Global Fund goes one step further to include the voice of developing country citizens by requiring that one NGO representative on its Board be either "a person living with HIV/AIDs or from a community living with tuberculosis or malaria." 55 As discussed below, the methods that institutions use to screen and continually monitor whether included NGOs have relevant experience and expertise have become increasingly sophisticated.

\section{Participation}

Participation connotes a continuum of ways in which those affected by an institution can participate. ${ }^{56}$ "The weakest form of participation is mere availability of information, or transparency...., 57 A more

51. See Spar \& Dail, supra note 5, at 172 (noting how "NGOs have become major conduits for development aid” and perform important community functions).

52. THE WORLD BANK, GP 14.70 - OpERATIONAL MANUAL: INVOLVING NONGOVERNMENTAL ORGANIZATIONS IN BANK-SUPPORTED ACTIVITIES para. 6 (July 1998) [hereinafter WBGP 14.70], available at http://go.worldbank.org/GLBEMFJEG0.

53. Id. para. 7.

54. See GEF-NGO NETWORK REVISED RUles, supra note 49, at 2-3; The GlobAL FUND TO FIGHT AIDS, TUBERCUlOSIS AND MALARIA, BY-LAWS art. 7.1 (2011), http://www.theglobalfund .org/documents/core/bylaws/Core_GlobalFund_Bylaws_en/ [hereinafter GLOBAL FUND BY-LAWs]. The NGO Coordination Committee of the GEF-NGO Network, for example, consists of up to fifteen NGO representatives elected from different geographic regions, along with three representatives of indigenous people's organizations from three main regions. GEF-NGO NETWORK REVISED RULES, supra note 49 , at $2-3$.

55. GLOBAL FUND BY-LAWS, supra note 54, art. 7.1. The Global Fund's by-laws also require that the NGO representatives include one representative of a developing country NGO and one representative of a developed country NGO. Id.

56. See Norman Uphoff, Fitting Projects to People, in PUTTING PEOPLE FIRST: SocIOLOGICAL VAriables in Rural DeVelopment 359, 377 tbl.12-1 (Michael M. Cernea ed., 1985) (listing different ways beneficiaries can participate in aid projects).

57. Monica Hlavac, A Developmental Approach to the Legitimacy of Global Governance Institutions, in COERCION AND THE STATE 203, 215 (D.A. Reidy \& W.J. Riker eds., 2008) (emphasis 
substantive form of participation allows a "two-way transferring of information” as, for example, when a national institution allows individuals to petition it as opposed to a "one-way offering of information from the [institution] to its subjects." 58 The strongest form of participation consists of equal voting rights. ${ }^{59}$ This Article is concerned with the participation of NGOs in institutional governance. This is distinguishable from NGO participation in project and program implementation, which is now routine at varying levels in both multilateral and bilateral development assistance. ${ }^{60}$ In fact, it is the very depth of their experience as implementers of international development projects that NGOs claim gives them currency and credence to participate in institutional governance. ${ }^{61}$ As detailed below, however, participation in governance can vary greatly in the degree of influence it allows.

\section{Legitimacy}

Legitimacy with regard to the governance of a state means the justified monopoly of power. ${ }^{62}$ When a state has justified power, it has legitimate authority. ${ }^{63}$ So, institutions are legitimate, that is, they have justified authority, when some justification exists for the power they wield. A criminal gang, for example, may wield power in the form of force and even have a monopoly of power within some area. But a criminal gang cannot wield authority because its use of power or force is not legitimated by any justification. ${ }^{64}$

omitted).

58. Id.

59. See id.

60. See Ngaire Woods, The Globalizers: The IMF, the World Bank, And Their BORROWERS 201 (2006) (describing the operational role of NGOs); Spar \& Dail, supra note 5, at 172 (noting that "NGOs have become major conduits for development aid").

61. See, e.g., Bleaney \& SAint-Laurent, supra note 20, at 11 (listing expertise as a key value of increased NGO participation).

62. See Bodansky, supra note 17, at 600 (defining legitimacy as "a quality that leads people ... to accept authority-independent of coercion, self-interest, or rational persuasion-because of a general sense that the authority is justified”); Allen Buchanan \& Robert O. Keohane, The Legitimacy of Global Governance Institutions, 20 ETHICS \& INT'L AFF. 405, 409-10 (2006) (“To say that an institution is legitimate implies that it has the right to rule even if it does not act in accordance with the rational self-interest of everyone who is subject to its rule.").

63. See Bodansky, supra note 17, at 601 (“'Legitimate authority' simply means 'justified authority'....").

64. See id. (listing examples of justifications that support legitimacy, including legality). 
For authority to exist, the people within the jurisdiction of the power must regard the power as legitimate. ${ }^{65}$ While state legitimacy entails the monopoly of power, a government can also delegate power within itself, as in executive bureaucracies, or outside itself, as in corporations. ${ }^{66}$ In both cases the state or the corporation's authority derives from some rational legal connection to the state that conferred it. The right of a state or rulemaking institution to command obedience independent of its impact on the immediate self-interest of the persons who have to obey, i.e., the legitimacy of the state or rulemaking institution, derives from its authority. ${ }^{67}$

The term "legitimacy" refers to two distinct concepts: normative legitimacy and sociological legitimacy. ${ }^{68}$ Authority is normatively legitimate if "it is justified in some objective sense."69 What justifies authority depends on arguments about moral, political, and legal theory. ${ }^{70}$ Normative legitimacy focuses on the qualities of the ruler that morally justify its authority. For example, authority may be deemed justified if it derives from a democratic process or, in other societies, from a divine right. ${ }^{71}$ The moral justification of authority has "normative consequences for those subject to the ... authority." authority is legitimate in the sociological sense if relevant audiences perceive it as justified and therefore accept it. ${ }^{73}$ This is an external test

65. See id. at 600 .

66. See MAX WeBer, Bureaucracy, reprinted in From MAX WeBER: ESSAYS In SOCIOLOGY 196, 196 (H.H. Gerth \& C. Wright Mills eds. \& trans., 1970) (describing the distribution of authority and bureaucracy in the public and private domain).

67. See Buchanan \& Keohane, supra note 62, at 409-10 (noting that an institution's legitimacy is not affected by its failure to act in the self-interest of people under its power).

68. Bodansky, supra note 17 , at 601 .

69. Id.

70. See id. at 602 (listing fairness, justice, consent, and other normative criteria as bearing on the question of legitimacy).

71. See id. at 601 (noting that a variety of factors might justify an actor's right to exercise authority including "tradition, rationality, legality, and democracy").

72. Bodansky, supra note 16, at 7. As noted by Bodansky, however, "[p]hilosophers disagree about the nature of those normative consequences.” Id. at 7 n.6. Some take the view that the right to rule "entails a corresponding moral duty to obey on the part of those subject to the institution's authority." Id. (citations omitted) (quoting JOSEPH RAZ, THE MORALITY OF FREEDOM (1986); A. John Simmons, Justification and Legitimacy, 109 ETHICS 739 (1999); John Tasioulas, The Legitimacy of International Law, in THE PHILOSOPHY OF INTERNATIONAL LAW 97 (Samantha Besson \& John Tasioulas eds., 2010)). "[O]thers conceptualize the right to rule as a power to create legal as opposed to moral duties.” Id. (citation omitted) (citing Arthur Isak Applbaum, Legitimacy Without the Duty to Obey, 38 PHIL. \& PUB. AfF. 215, 221 (2010)).

73. See Buchanan \& Keohane, supra note 62, at 405 (stating that wide belief in an institution's right to rule constitutes sociological legitimacy). 
that includes moral justifications, although it does not make any judgment about the validity of those justifications. ${ }^{74}$ The answer to what makes an institution's authority sociologically legitimate depends on empirical and explanatory arguments about what people believe and why. ${ }^{75}$ This Article's discussion of legitimacy centers on international development institutions' normative legitimacy. Although legitimacy is often used to describe what NGO participation contributes to an international development institution, I maintain that legitimacy is actually the wrong frame within which to consider what NGOs bring to the table.

\section{B. How Legitimacy Is Determined}

The legitimacy of international institutions, including international development institutions, has attracted considerable attention in recent scholarship. ${ }^{76}$ The normative and sociological legitimacy of international

74. See Bodansky, supra note 16, at 8 (describing descriptive legitimacy as "conceptually parasitic on normative legitimacy").

75. See id. at 14-15. The sociological legitimacy of international institutions depends on the answers to a set of empirical inquiries about the kinds of factors and qualities that would make an international institution's authority accepted. Id. "International institutions have multiple audiences and constituencies and affect many different actors. So[,] a wide variety of actors are potentially relevant in determining an institution's . . legitimacy.” Id. at 16. The first challenge in assessing an international institution's legitimacy, therefore, is to identify the relevant actors to be surveyed. Even when the relevant actors are identified, however, further difficulties arise in determining their views on an institution's legitimacy. See id. at 17 (noting "any methodology w[ould] be imperfect and often it may be impracticable to get the necessary evidence”). An international institution's actors and audiences may also have widely differing views of the definition of legitimacy. Id. at 18.

76. See, e.g., Michael N. Barnett \& Martha Finnemore, The Politics, Power, and Pathologies of International Organizations, 53 INT'L ORG. 699 (1999); Bodansky, supra note 16; Daniel C. Esty, Good Governance at the Supranational Scale: Globalizing Administrative Law, 115 YALE L.J. 1490, 1495, 1515-23 (2006) (arguing "institutions must adopt basic administrative law procedures to achieve better results and bolster public confidence [in them]" and discussing types of legitimacy); Benedict Kingsbury, Nico Krisch \& Richard B. Stewart, The Emergence of Global Administrative Law, LAW \& CONTEMP. PROBS., Summer/Autumn 2005, at 15, 16-17 (noting organizations are looking to administrative law procedures to boost legitimacy). International institutions pose a legitimacy concern because they often exercise broad powers that have a major impact on the lives of citizens in the countries affected by them. See Hlavac, supra note 57, at 206 ("The particular critique that [global governance institutions (GGIs)] lack legitimacy embodies a very specific concern, that GGIs wield power by directing rules towards states that adversely affect people, yet are not accountable for this power. This concern specifically targets GGI activities occurring beyond the control of those affected by them.”). The scale of this impact prompts consideration of whether these institutions' exercise of authority is justified. Why should these nameless, faceless international entities have the power to constrain and interfere with individuals' freedoms? Impact is irrelevant to legitimacy, but impact gets our attention nevertheless. See Esty, supra, at 1512-14 (suggesting that concern about the legitimacy of an international institution increases in proportion to the degree to which the issues the institution seeks to address are politically sensitive and 
institutions depends on the same sources of authority that states rely on to justify their right to rule, such as democratic accountability, religion, and tradition. ${ }^{77}$ Yet, just as individual states can delegate authority to rational bureaucracies to implement their decisions, states acting together can also create a bureaucracy to implement their collective will. In those circumstances, the legitimacy of that institution depends upon the extent to which it carries out the will of the original states whose legitimacy it rests upon. ${ }^{78}$

If a bureaucracy exceeds the power granted to it, fails to exercise its power to solve the problem it was created to eliminate, or uses its power foolishly or corruptly so as to fail to solve its assigned task, that bureaucracy will be ineffective or worse. ${ }^{79}$ Such an institution lacks credibility because, like a machine that malfunctions, it cannot achieve its intended, legitimate, ends. A bureaucracy's only purpose is to rationally implement the will of the states that created it. ${ }^{80}$ Absent that ability, or commitment, there is no justification for its exercising the power granted it. Evaluating the legitimacy of a bureaucracy, therefore, is different from evaluating the legitimacy of the state institutions that created it. Unlike the normative questions of justice by which states are judged, bureaucracies are judged by their ability to achieve specific ends. $^{81}$

As Monica Hlavac observes, "institutions [vary] in their capacities and functions, and as they do what legitimacy demands of them [varies] too."82 Any test of an institution's legitimacy, therefore, should take

normatively charged, and examining legitimacy implications in different scenarios).

77. See Bodanksy, supra note 16 , at 5.

78. But cf. Barnett \& Finnemore, supra note 76, at 709 ("The legitimacy of rational-legal authority suggests that [international organizations] may have an authority independent of the policies and interests of states that create them . . ..”).

79. See id. at 715 .

80. See WEBER, supra note 66, at 196 (stating that bureaucracies need to fulfill the duties delegated to them by their creator).

81. See id.

82. Hlavac, supra note 57, at 210. "If we specify broad conditions for [international institution] legitimacy we run the risk of abstracting away from important differences among [international institutions].” Id. at 209. This approach differs from the uniform approach taken by some scholars, notably, Allen Buchanan and Robert Keohane. Referring to international institutions as "global governance institutions” (GGIs), Buchanan and Keohane offer an ad hoc approach, which they label a "complex standard of legitimacy," as a test for assessing the legitimacy of GGIs. Buchanan \& Keohane, supra note 62, at 432. The standard is comprised of three elements:

First, [GGIs] should enjoy the ongoing consent of democratic states. . . Second, [GGIs] should satisfy the substantive criteria of minimal moral acceptability, comparative benefit, and institutional integrity. Third, [GGIs] should possess the epistemic virtues needed to make credible judgments about whether the three substantive criteria are 
account of the following: (1) the type of authority the institution exercises, (2) the issues involved, and (3) the degree to which the authority exercised is autonomous and binding. ${ }^{83}$ The kind of authority international development institutions are created to wield, for example, is clearly distinguishable from the kind of authority legislatures or adjudicatory bodies wield. The closest domestic analogy to the kind of authority an international development institution wields is the kind exercised by governmental administrative agencies or executive bureaucracies, such as the authority of the Department of Transportation or United States Agency for International Development.

The analogy between the kind of authority exercised by many U.S. administrative agencies and certain international institutions whose origins and function are like administrative agencies is well documented. ${ }^{84}$ Strong parallels exist between the recent proliferation of international institutions and emerging concerns about their legitimacy, and the proliferation of administrative agencies in the United States and

satisfied and to achieve the ongoing contestation and critical revision of their goals, their terms of accountability, and ultimately their role in a division of labor for the pursuit of global justice, through their interaction with effective external epistemic agents. Id. at 432-33.

The Buchanan-Keohane standard does not differentiate between the nature of the governance-like powers an institution has been created to exercise, i.e., adjudicatory, legislative, regulatory, or some combination thereof. In their view, therefore, the legitimacy of the International Criminal Court (which they expressly include within the definition of GGI), id. at 406, can and should be judged according to the same standard as an international development institution such as the World Bank. Recent scholarly critiques of the Buchanan-Keohane approach favor a more localized approach. See, e.g., Hlavac, supra note 57, at 223. Buchanan and Keohane make a significant contribution to the issue of international institution legitimacy. They correctly identify a strong need for a standard on which to base principled criticism of international institutions. See Buchanan \& Keohane, supra note 62, at 405 (noting disagreement exists on the concept of normative legitimacy). They also usefully underscore the key aspects of an institution that such a criticism should address, such as comparative benefit, institutional integrity, and transparency. Id. at 422-24, 427-29. Their argument that such a standard should be different from the standard of legitimacy that applies to a sovereign state's exercise of legislative power, see id. at 406 (stating the differences between governments and international institutions), is also persuasive. But it is not clear why from that conclusion they make the leap that one standard of legitimacy for international institutions should fit all. A second weakness in their approach is that they assume that the normative legitimacy of an institution is key to an institution's capacity to deliver the benefits it has been created to provide. Id. at 408. In fact, this assumption may not be true as an empirical matter. See Bodanksy, supra note 16, at 18-19 (noting the need for empirical studies on whether actors' perceptions of legitimacy, which can be based on normative factors, contribute to an institution's success).

83. Bodansky, supra note 16 , at 14 .

84. See Kingsbury, Krisch \& Stewart, supra note 76, at 17 (arguing that "much of global governance can be understood and analyzed as administrative action," distinguishable from acts that are either legislative or judicial); see also Esty, supra note 76, at 1494 (arguing that rules and procedures associated with administrative law can lend legitimacy to global institutions). 
[Vol. 61

similar related concerns in the wake of the New Deal. ${ }^{85}$ The upshot of these parallels is that the test that has evolved for evaluating the legitimacy of U.S. administrative agencies and their exercise of their power can serve as a useful guide for evaluating the legitimacy of analogous international institutions.

That test for the legitimacy of a U.S. administrative agency crystallized when the New Deal Congress created "a raft of new federal regulatory agencies and endowed them with very broad powers." Democratic anxieties intensified in the face of this expansive delegation of governmental power. ${ }^{87}$ The new federal agencies were attacked as a fourth, and illegitimate, branch of government. ${ }^{88}$ In defense of the agencies' legitimacy, James Landis "appealed to the notion of regulatory management by experts.” ${ }^{\circ 9}$ The new agencies, he argued, were staffed by "expert administrators [who] would adopt measures to secure... public interest goals." 90 The source of the agencies' authority was their normative legitimacy: their expertise ${ }^{91}$ and an express mandate from Congress. $^{92}$

\section{Legitimacy as Efficacy}

The principle that an institution's legitimacy is (a) derived from the legitimacy of the government that created it and (b) a product of the degree to which it complies with its predetermined nonadjudicatory mandate, applies equally to an intergovernmental bureaucracy. This principle, although applied by U.S. courts to clarify the legitimacy of the U.S. regulatory state, ${ }^{93}$ was not hatched in U.S. jurisprudence. Rather, it

85. See Esty, supra note 76, at 1494.

86. Richard B. Stewart, Administrative Law in the Twenty-First Century, 78 N.Y.U. L. REV. 437, 440 (2003).

87. Id. (citing McNollgast, The Political Origins of the Administrative Procedure Act, 15 J.L. ECON. \& ORG. 180, 191-92 (1999)).

88. Id. (citing Peter L. Strauss, The Place of Agencies in Government: Separation of Powers and the Fourth Branch, 84 COLUM. L. REV. 573 (1984)).

89. Id. (citing James M. LANDis, THE AdMinistrative PROCESS 6-46 (1938)).

90. Id. at 441.

91. Id. at 440-41.

92. See Edward L. Rubin, Law and Legislation in the Administrative State, 89 COLUM. L. REV. 369, 371-75 (1989) (analyzing legislation as directives given to implementers such as agencies).

93. See, e.g., Morton v. Ruiz, 415 U.S. 199, 232 (1974) ("[A]gency power to make rules that affect substantial individual rights and obligations carries with it the responsibility ... to remain consistent with the governing legislation ....”). 
dates back to classic Weberian analysis of bureaucracy. ${ }^{94}$ In short, the ultimate test of a bureaucracy's legitimacy is its efficacy. Efficacy, as used in this Article, means the extent to which a bureaucracy complies with the mandate predetermined for it by the state or states that created it, in accordance with any rules and procedures established by the state or states.

Importantly, efficacy is not merely effectiveness. The effectiveness of a state agency relates only to its ability to achieve the goals assigned to it. However, an agency is efficacious when it accomplishes the assigned task using only the powers delegated to it, and the procedures it is permitted to use. For example, if the U.S. Department of Transportation (DOT) is asked to eliminate traffic jams, it could accomplish this by studying the causes of the situation and suggesting alternative driving practices, transportation mixes, or other civil engineering designs. ${ }^{95}$ Alternatively, the DOT could set out to shoot every third car owner. No doubt the latter option would be effective but it would not be efficacious. Legitimacy, therefore, requires not only that an agency meets its goals, but that it do so using only those powers prescribed to it by the legislature. This confluence of procedural justice and effectiveness are the basis of bureaucratic legitimacy.

Although the standard for evaluating the legitimacy of a bureaucracy includes questions of procedural justice, ${ }^{96}$ appropriate procedures for a bureaucracy differ from those that would be appropriate for other institutions of the state. ${ }^{97}$ For example, to be just, a legislature requires equal representation. Yet, we would not consider holding a general election to determine whether someone is guilty of a crime to be appropriate procedure. Instead, adjudication is the correct procedure for a court to employ. A court must achieve the goals assigned to it by using the procedures that are appropriate to adjudicating the law. For a bureaucracy, legitimacy rests in rationally applying its substantive expertise to solve the problems assigned to it. In other words, legitimacy for a bureaucracy rests on its efficaciousness. And efficaciousness

94. See WEBER, supra note 66, at 196 (describing characteristics of bureaucracies including state delegation of duties and bureaucracies' fulfillment of these duties).

95. See 49 U.S.C. § 301 (2006) (listing duties of the Secretary of Transportation, including "promot[ing] and undertak[ing] research and development related to transportation").

96. See Bodansky, supra note 16, at 3 (naming the procedural factors of transparency, participation, and neutrality as part of the concept of legitimacy).

97. See JOHN RAWLS, A THEORY OF JUSTICE 86 (1971) (noting that "background circumstances define a fair procedure"). 
means applying its expertise to successfully achieve the goals assigned to it.

Sometimes, however, an agency cannot be efficacious not because the ends are unachievable but because it has not been given the authority to use the procedures necessary to solve the problem assigned to it. Suppose, for example, that a state decides to provide financing to help address the problem of HIV/AIDS in the developing world. Its legislature appropriates \$25 million to the state's development aid agency for the purpose of preventing the spread of HIV/AIDS. However, the legislation provides that the agency may employ only expertise founded in the King James version of the Bible. This leads the agency to reject any birth control measures and pursue an abstinenceonly policy. ${ }^{98}$ In this case, the agency follows the procedures given it, but the expertise fails to solve the problem. In this case the agency is employing legitimate authority but it is neither efficacious nor effective.

Merely following the will of the delegating authority is not necessarily sufficient to make an agency effective. For an agency of government to be effective, it must (a) be given procedures to follow that can achieve the goals assigned to it, and (b) follow the procedures assigned to it. ${ }^{99}$ Under this standard, legitimacy for a bureaucratic institution does not require widespread representation. That procedure is required at the legislative stage. Rather, legitimacy for a bureaucracy requires that it possess appropriate expertise to rationally apply to a problem to achieve assigned goals. ${ }^{100}$

If this is true, then it is not NGOs' ability to represent more diverse viewpoints in an international development institution's decision-making that lends legitimacy to the institution. Rather, NGOs might enhance the legitimacy of the institution by using their expertise and experience to develop methods for solving the problems assigned to it. In the case of the World Bank, some scholars believe that the Bank's modus operandi, making loans for projects and structural adjustment, are as ill-suited to development as abstinence-only measures are to stopping the spread of HIV/AIDS. ${ }^{101}$ If so, the Bank may be destined for the dust bin of history.

98. See 1 Corinthians 6:18 (King James) (commanding that one should "[f]lee fornication”).

99. See RAWLS, supra note 97, at 86 (noting the importance of "a correct or fair procedure" and proper compliance with such procedure).

100. See WEBER, supra note 66, at 216 ("The more complicated and specialized modern culture becomes, the more its external supporting apparatus demands the personally detached and strictly 'objective' expert ....”).

101. See, e.g., Pincus \& Winters, supra note 19, at 17 (stating that the assumption that the 
However, other scholars argue that the Bank's loan methodology is perfectly suited to the task so long as it is used for the correct policies. ${ }^{102}$ If NGOs can use their expertise to help the loan programs of the Bank more effectively achieve development, then their participation will prove both effective and efficacious. As a consequence, they will help protect the legitimacy of the Bank as a development institution.

\section{International Development Institution Efficacy}

International development institutions clearly qualify as international administrative entities. The status of the World Bank-one of the world's oldest and largest international development institutions ${ }^{103}$-as an international bureaucracy is well-established. ${ }^{104}$ Indeed, as captured by Ngaire Woods, the founders' vision of the Bank was as a consummate Weberian bureaucracy:

The founders of the IMF and World Bank created them to help balance growth in the world economy. They wrote charters for the institutions directing them to .... [inter alia,] develop the productive resources of all member countries. In each institution these goals were to be achieved through a pooling of resources, credit risk, and information and research capacity.... Politics and political influence would be kept out of [the] institutions. Boards of proficient technocrats would run them, and highly trained economists would staff them. ${ }^{105}$

While the vision of the World Bank and the IMF as nonpolitical institutions was not realized, ${ }^{106}$ their essential character as bureaucracies remains accurate. Similarly, the founding members of the United Nations Development Programme (UNDP), the UN entity with primary responsibility for the UN's development activities, ${ }^{107}$ saw UNDP as an

\footnotetext{
“content, design, and implementation” of Bank policies are beyond criticism is not warranted); John Sender, Reassessing the Role of the World Bank in Sub-Saharan Africa, in REINVENTING THE WORLD BANK, supra note 4, at 185, 189 (noting that "the World Bank's policy prescriptions have always been predicted by heterodox economic theory to be harmful to the development prospects of sub-Saharan Africa”).

102. See Pincus \& Winters, supra note 19, at 15-16 (discussing arguments for aid selectivity).

103. See WoODs, supra note 60, at 7 (noting that the Bank's staff numbers more than 10,000 and it was created in the 1940s).

104. See Barnett \& Finnemore, supra note 76, at 709-10 (noting the Bank's bureaucratic characteristics); Pincus \& Winters, supra note 19, at 1.

105. WoODS, supra note 60, at 2.

106. See id.

107. The UN's development work is spread across multiple entities, including UNDP, and
} coordinated by ECOSOC. KARNS \& MINGST, supra note 48, at 115 . The UN is "a source of 
entity that would provide technical training to developing countries (technical assistance) in a range of areas. ${ }^{108}$ As government bureaucracies, therefore, these institutions' legitimacy depends, firstly, on their efficacy, i.e., the degree to which they comply with their member-imposed mandates.

So what is an international development institution's mandate? The mandate of all international development institutions is to finance the general and specific development needs of developing countries. ${ }^{109}$ They

economic and technical assistance for numerous underdeveloped countries." Pierre de Senarclens, The United Nations As a Social and Economic Regulator, in REgulating GLOBALIZATION: Critical Approaches to Global Governance 8, 9 (Pierre de Senarclens \& Ali Kazancigil eds., 2007). Although the "maintenance of peace was the main objective for the foundation of the United Nations Organization," its founders believed that governments could not achieve international security without "strong international cooperation aimed at promoting economic progress and social welfare, ... g. goals . . . reflected in Article 55 of the United Nations Charter." Id. at 10. "Various UN-related organizations, such as the UNDP, the United Nations Children's Fund (UNICEF), the Food and Agriculture Organization (FAO), the World Food Programme (WFP), and the World Health Organization (WHO)” provide development assistance. J. SAMUEL BARKIN, INTERNATIONAL ORGANIZATION: THEORIES AND INSTITUTIONS 107 (2006). Of these, UNDP is the most directly focused on development, providing technical assistance to countries in need. Id. UNDP, established in 1965, is governed by an Executive Board consisting of thirty-six rotating members. THOMAS WINDERL, UNDP JPO SERVICE CENTRE, UNDP FOR BEGINNERS: A BEGINNER'S GUIDE TO THE United NAtions Development Programme 4, 14 (4.1 ed. 2011), http://www.jposc.org/ documents/UNDP_for_Beginners_en.pdf. The Board aims to operate by consensus. Decisions of the Executive Board, UnITED NATIONS DEV. Programme, http://www.undp.org/content/undp/en/ home/operations/executive_board/decisions_of_theboard/ (last visited Sept. 20, 2012). Its regular funding derives from voluntary contributions from governments of member states. WINDERL, supra, at 23 .

108. See LAWRENCE Ziring, ROBERT Riggs \& JACK Plano, The United NATiONs: INTERNATIONAL ORGANIZATION AND WORLD POLITICS 495-96 (4th ed. 2005) (noting that technical assistance, involving the "teaching of skills and new technologies," accounted for a significant portion of the energies and funds of programs like UNDP).

109. See, e.g., Articles of Agreement of the International Bank for Reconstruction and Development, Dec. 27, 1945, art. I, 60 Stat. 1440, 2 U.N.T.S. 134 [hereinafter IBRD Articles of Agreement]; Instrument for the Establishment of the Restructured Global Environment Facility, Mar. 16, 1994, 33 I.L.M. 1273, para. 2, at 1285 [hereinafter GEF Instrument]; THE GLOBAL FUND TO FIGHT AIDS, TUBERCULOSIS AND MALARIA, FRAMEWORK DOCUMENT § II (2001) [hereinafter GLOBAL FUND FRAMEWORK DOCUMENT], available at http://www.theglobalfund.org/en/library/ documents (under "Core Documents" heading); A World of Development Experience, UNITED NATIONS DeV. Programme, http://www.undp.org/content/undp/en/home/operations/about_us.html (last visited Sept. 21, 2012).

The specific contractual nature of the World Bank and other development institutions' interactions with borrower and recipient countries casts doubt on whether international development institutions are properly classified as global governance institutions, as, for example, Monica Hlavac has classified global governance. Hlavac, supra note 57, at 203. Governance, it is generally held, "involves making decisions for a collective-decisions that not merely affect others indirectly, but are directed at them and are intended, in some way, to constrain their behavior.” Bodansky, supra note 16 , at 5 . The decisions have an other-directed quality that "substitute[s] the ruler's judgment for that of its subjects." Id. While Bank loans and other development assistance agreements have the effect of imposing sweeping terms and conditions on borrowing and recipient countries, it is not 
fulfill this mandate by entering into contractual arrangements with borrowing or recipient countries on a case-by-case basis. ${ }^{110}$ These institutions do not govern in the sense of issuing rules or regulations. Instead, their common mandate is to serve as financial intermediaries.

Though much has been written about World Bank mission creep, ${ }^{111}$ the essential nature of the Bank has not changed since its creation. While the reasons the Bank's members created it and continue to support it are deeply embedded in their foreign affairs agendas and vary over time, the specifics of the mandate within which the institution operates does not. The Bank is a financial institution, in essence a purveyor of loans and guarantees. $^{112}$ Its Articles of Agreement lay out the institution's financing mandate with considerable specificity. ${ }^{113}$

clear that these terms and conditions amount to governance. True, Bank loans are contracts of adhesion for all but its most powerful borrowers. See WooDs, supra note 60, at 70-72; Christine Cassar, Can Recipient Countries Really Say No to Conditional Aid?, WORLD BANK (Oct. 7, 2009, 7:19 AM), http://blogs.worldbank.org/youthink/can-recipient-countries-really-say-noconditional-aid. Further, conditionality, especially in development policy lending where the Bank may prescribe sweeping governmental reforms, has the appearance of the Bank imposing its judgment on the borrowing country where the country is desperate for funds and in no position to negotiate. But to view such loans as governance ignores the fact that the loan is, however desperately needed, voluntarily assumed. At bottom, an international development institution's authority to set terms and conditions is contractually based. It is not broadly consensual, arising from a multilateral treaty; it is specifically consensual, arising from a loan or grant agreement entered into on a one-on-one basis between the institution and the borrower or recipient.

However, "governance can vary widely in its coerciveness," ranging from hard power to soft power; "non-binding regimes lack coercive power, [but] they still [can] be said to 'rule' to the extent that they intend their decisions to guide others." Bodansky, supra note 16, at 5-6. "[S]oft power 'co-opts people rather than coerces them.'” Hlavac, supra note 57, at 207 (quoting JoSEPH S. NYE, JR., THE PARADOX OF AMERICAN POWER: WHY THE WORLD'S ONLY SUPERPOWER CAN’T GO IT ALONE 9 (2002)). In response to the observation that "harmonization among national laws ... frequently results from World Bank activity," id. (citing Andre Rigo, Address at the University of Ottawa Conference on Globalization and the Evolution of Legal Systems: Law Harmonization Resulting from the Policies of International Financial Institutions: The Case of the World Bank (Oct. 2000)), some scholars take the view that the Bank's lending practices amount to a form of soft law. See id. (citing ANNE-MARIE SLAUGHTER, A NeW WORLD ORDER 179 (2004)). Others maintain that the Bank's lending activities amount to governance because they cumulatively have the effect of norm diffusion. See Barnett \& Finnemore, supra note 76, at 714 (noting the Bank's power in defining development and norms and transmitting such information to developing countries (citing Robert Wade, Japan, the World Bank, and the Art of Paradigm Maintenance: The East Asian Miracle in Political Perspective, New Left ReV., May-June 1996, at 3)).

110. See, e.g., IBRD Articles of Agreement, supra note 109, art. III; GEF Instrument, supra note 109, para. 9; GLOBAL FUND FRAMEWORK DOCUMENT, supra note 109, § III.

111. See, e.g., Daniel D. Bradlow, International Law and the Operations of the International Financial Institutions, in INTERNATIONAL FINANCIAL INSTITUTIONS AND INTERNATIONAL LAW 1, 15-16 (Daniel D. Bradlow \& David B. Hunter eds., 2010) (summarizing scholarly criticism of mission creep); Bruce Rich, The World Bank Under James Wolfensohn, in ReINVENTING THE WORLD BANK, supra note 4, at 26, 37 (noting that "[t]he Bank under [James] Wolfensohn at times appeared to be trying to be all things to all people").

112. See WORLD BANK INFORMATION STATEMENT, supra note 12, at 12-18, 129-20 (describing 
Loans and guarantees are to be made for productive purposes, for specific projects, ${ }^{114}$ and only to member countries who cannot borrow from other sources on reasonable terms. ${ }^{115}$ Further, the Bank's Articles of Agreement are specific about the conservative nature of the financing policies they want the Bank to observe. For example, they specify that the guarantees and loans provided by the Bank must not exceed its "unimpaired subscribed capital, reserves and surplus." of the Bank's mandate serve a clear purpose. The Bank generates its operating capital by issuing bonds on international capital markets. ${ }^{117}$ The Bank's member countries guarantee its payment of principal and interest on those bonds. ${ }^{118}$ Accordingly, the specificity of the Bank's operational mandate is aimed at setting out its purposes while simultaneously limiting the scope of its nonborrowing member countries' financial exposure to investors in Bank bonds.

Newer, sector-specific institutions like the GEF and the Global Fund have narrower mandates. The GEF, for example, helps developing country signatories to the United Nations Framework Convention on Climate Change (UNFCCC) and the United Nations Convention on Biodiversity (the Convention on Biodiversity) meet the expense of complying with their commitments under those conventions. ${ }^{119}$ Comprised of 182 member governments, the GEF is a multibillion dollar fund that helps to finance projects in developing counties that contribute to environmental protection in six focal areas: "biodiversity, climate change, international waters, land degradation, the ozone layer, and persistent organic pollutants." 120 The terms of the conventions for which

the Bank's lending activities and the types of guarantees it offers). Although the Bank engages in other activities, such as administering trust funds and providing investment management services to developing countries, it is primarily a lending institution. Id. at 20-21.

113. See IBRD, Articles of Agreement, supra note 109, art. I.

114. Id.

115. Id. art. III, § 4(ii).

116. Id. art. III, § 3 .

117. See World BANK Information Statement, supra note 12, at 26-29 (listing and explaining various securities issued by the Bank).

118. See id. at 25 (detailing the extent of IBRD's callable capital).

119. See Sophie Smyth, A Practical Guide to Creating a Collective Financing Effort to Save the World: The Global Environment Facility Experience, 22 GEO. INT’L ENVTL. L. REV. 29, 32, 36-37 (2009). Since its creation, the GEF has also become a source of financing to developing countries to help meet the costs of their compliance with the Stockholm Convention on Persistent Organic Pollutants and the United Nations Convention to Combat Desertification. Conventions, GLOBAL ENV'T FACILITY, http://www.thegef.org/gef/structure-conventions (last visited Sept. 22, 2012).

120. What is the GEF, GLOBAL ENV'T FACILITY, http://www.thegef.org/gef/whatisgef (last visited Sept. 22, 2012). 
the GEF serves as a financing mechanism dictate the broad parameters of the financial assistance it provides. ${ }^{121}$

The Global Fund's mandate is focused on the eradication of HIV/AIDS, tuberculosis, and malaria. ${ }^{122}$ It emerged from the July 23, 2000 commitment of the leaders of the 26th G8 Summit to "implement an ambitious plan" to address these diseases. ${ }^{123}$ Like the GEF, the Global Fund is a multibillion dollar fund. ${ }^{124}$ It finances a wide range of activities in developing countries aimed at these diseases, including preventing their spread, treating people who are ill, and providing care and support for affected people and communities. ${ }^{125}$

Implementing an international development institution's mandate, therefore, primarily consists of setting the specific terms and conditions on which the institution will provide financing to a borrowing or recipient country within the parameters of the institution's overall purposes. Whether an institution's mandate is broad or specialized, the terms and conditions it imposes on a borrowing or recipient country will have a significant impact on that country's citizens. In many cases, that impact will be as significant as the impact of that country's legislation. ${ }^{126}$

Neither the impact of an international development institution's activities, however, nor its effectiveness in correctly calibrating its terms and conditions so as to achieve its purposes, changes the bottom line on

121. GEF Instrument, supra note 109, paras. 9(a), 27.

122. GLOBAL FUND FRAMEWORK DOCUMENT, supra note 109, § II.

123. G8, G8 Communiqué Okinawa 2000, para. 19 (July 23, 2000), http://www.g8.utoronto.ca/ summit/2000okinawa/finalcom.htm. The idea of creating a special purpose fund took shape during a special summit of the Organization of African Unity. See African Summit on HIV/AIDS, Tuberculosis and Other Related Infectious Diseases, Abuja, Nigeria, Apr. 24-27, 2001, Abuja Declaration on HIV/AIDS, Tuberculosis and Related Infectious Diseases, I 29, U.N. Doc. OAU/SPS/ABUJA/3 (Apr. 27, 2001), http://www.un.org/ga/aids/pdf/abuja_declaration.pdf. At that meeting, participants pledged to "support the creation of a Global AIDS Fund capitalized by the donor community to the tune of US \$5-10 billion accessible to all affected countries to enhance operationalization of Action Plans, including accessing Anti-retroviral programmes ...." Id. Also at that meeting, African leaders rallied behind the proposal of then-UN Secretary-General Kofi Annan for "the creation of a Global Fund, dedicated to the battle against HIV/AIDS and other infectious diseases.” Annan Press Release, supra note 15. The UN General Assembly announced "[s]upport [for] the establishment ... of a global HIV/AIDS and health fund to finance an urgent and expanded response to the epidemic" at the conclusion of the UN General Assembly Special Session in June 2001 and welcomed pledges from donor nations and the private sector. G.A. Res. S-26/2, supra note 15 , ๆ 90.

124. See Who We Are, Global Fund to Fight AIDS, Tuberculosis \& Malaria, http://www.theglobalfund.org/en/about/whoweare/ (last visited Sept. 22, 2012).

125. Our Activities, GLOBAL FUnd TO Fight AIDS, TUBERculosis \& MALARIA, http://www.theglobalfund.org/en/activities/ (last visited Sept. 22, 2012).

126. See StigliTZ, supra note 2, at 43-44 (noting that some agreements between the IMF and recipient countries even "stipulated what laws the country's Parliament would have to pass"). 
these institutions' legitimacy. The institution's normative legitimacy is assured as long as the terms and conditions it imposes are: (a) related to advancing the purposes for which it has been created, and (b) follow whatever requirements and procedures are prescribed in its mandate. ${ }^{127}$ For these reasons, NGO participation in an international development institution's governance will be critical to that institution's legitimacy only if the institution's express or implied mandate (which may evolve as an institution evolves) requires it.

\section{E. Efficacy and NGOs}

The members of international development institutions generally keep the institutions on a short leash. They retain key decision-making authority for themselves rather than delegating it to institutional management. This tendency is evident in both established institutions like the World Bank and in newer institutions like the GEF. In both cases, member governments retain considerable power to make all significant decisions, ranging from decisions on overall strategy to specific loan approvals and grant allocations. They do not surrender power over these decisions to institutional management. Moreover, they do not necessarily share power equally among themselves or with others.

In the governance structure of the Bank, for example, the Board of Executive Directors, comprised of member government

127. See supra Part II.C. An institution's legitimacy can, however, be impugned if it fails to comply with its mandate. See Buchanan \& Keohane, supra note 62, at 423. Further, that mandate can change over time. See Daniel D. Bradlow, International Organizations and Private Complaints: The Case of the World Bank Inspection Panel, 34 VA. J. INT'L L. 553, 557 (1994) (noting that the scope of the Bank's general mandate changes under each leader). For example, when the World Bank established certain procedures and then routinely failed to observe them, see id. at 563 (discussing the Bank's violations of internal rules and procedures relating to a development project in India), action which ultimately prompted the creation of the World Bank Inspection Panel, Int'l Bank for Reconstruction \& Dev. \& Int'l Dev. Ass'n, “The World Bank Inspection Panel”, Res. No. IBRD 93-10, Res. No. IDA 93-6 (Sept. 22, 1993), http://siteresources.worldbank.org/ EXTINSPECTIONPANEL/Resources/ResolutionMarch2005.pdf, it was acting illegitimately. Once approved and adopted, those safeguards became a part of its mandate. Note, the World Bank Inspection Panel was created in response to the findings of the Morse Commission and private sector criticism. INT'L BANK FOR RECONSTRUCTION \& DEV., THE WORLD BANK, ACCOUNTABILITY AT THE WORLD BANK: THE INSPECTION PANEL 10 YEARS ON 2 (2003), http://siteresources .worldbank.org/EXTINSPECTIONPANEL/Resources/TenYear8_07.pdf. The Morse Commission was an independent review of the Bank commissioned to investigate allegations made by a broad grassroots campaign that Bank policies were violated in the Bank-financed project to fund the Sardar Sarovar dam and canal on the Narmada River in India. Id. When the Commission validated the allegations, finding that the violations had had "devastating human and environmental consequences," the Bank created the Inspection Panel to quell international pressure for greater public accountability in Bank lending. Id. at 2-3. 
representatives, ${ }^{128}$ is the locus of power. ${ }^{129}$ All Bank operational policies and loans are approved by the Board, a standing body that meets twice a week. ${ }^{130}$ Further, the Board operates pursuant to a weighted voting system according to which the largest Bank shareholders hold the largest number of votes. ${ }^{131}$ This weighted voting system allows the most powerful and largest contributors to have the largest say, ${ }^{132}$ reflecting what I call the "paymaster principle." UNDP, too, is governed by a thirty-six member executive board made up of member country representatives. ${ }^{133}$ The UNDP Executive Board reaches decisions through consensus. ${ }^{134}$

Member countries also hold the reins in the GEF, with the largest contributors having the biggest say. A secretariat manages the GEF's day-to-day operations. ${ }^{135}$ The GEF's locus of power, however, is the GEF Council, the body that sets the GEF work program and decides

128. Mallaby, supra note 39, at 83

129. See Ngaire Woods, The Challenge of Good Governance for the IMF and the World Bank Themselves, 28 WORLD DEV. 823, 831-32 (2000) [hereinafter Woods, The Challenge] (describing the powers and roles of the Board). The Bank is made up of a Board of Governors, a Board of Executive Directors (the Board of EDs), and a President and staff who answer to the Board of EDs. IBRD, THE WORLD BANK, ORgANIZATION CHART OF THE WORLD BANK (July 1, 2012), http://siteresources.worldbank.org/EXTABOUTUS/Resources/bank.pdf. On most matters, the Board of EDs operates by a "consensus, and voting is very rare." Ngaire Woods, Holding Intergovernmental Institutions to Account, 17 ETHICS \& INT’L AFF. 69, 76-77 (2003) [hereinafter Woods, Intergovernmental Institutions]. All member countries of the Bank are represented on the Board of EDs but they do not have an equal amount of power or votes. See THE WORLD BANK, INTERNATIONAL BANK FOR RECONSTRUCTION AND DEVELOPMENT SUBSCRIPTIONS AND VOTING POWER OF MEMBER COUNTRIES (Oct. 12, 2012), http://sitesources.worldbank.org/BODINT/ Resources/278027-1215524804501/IBRDCountryVotingTable.pdf. Countries may become members of the Bank if they are members of the IMF. Boards of Directors: Voting Powers, WORLD BANK, http://go.worldbank.org/VKVDQDUC10 (last updated July 6, 2012). The amount of shares each country has in the Bank is determined by the size of its economy at the time when it becomes a member. See WORLD BANK INFORMATION STATEMENT, supra note 12, at 53. The number of votes each Executive Director has, however, is determined according to the number of shares held by the country or countries that she represents. This system of voting is known as a weighted voting system. See Woods, The Challenge, supra, at 828.

130. Boards of Directors: Executive Directors, WORLD BANK, http://go.worldbank.org/ 1UZ5779V10 (last visited Sept. 23, 2012).

131. See Woods, The Challenge, supra note 129, at 828.

132. See id.

133. Executive Board, United NATIONS Dev. Programme, http://www.undp.org/content/undp/ en/home/operations/executive_board/overview.html (last visited Sept. 23, 2012).

134. Decisions of the Executive Board, supra note 107.

135. See GEF Instrument, supra note 109, para. 21, at 1289-90. The Secretariat is headed by a Chief Executive Officer, selected by the GEF Council. Id. para. 21, at 1289. The Secretariat's responsibilities include implementing Council decisions, commissioning reports and reviews requested by the GEF Council, and handling the logistics of meetings. Id. para. 21, at 1289-90. 
grant by grant how the GEF's resources will be spent. ${ }^{136}$ The GEF Council includes thirty-two member countries and operates by consensus. ${ }^{137}$ The GEF's founding charter, however, includes a mechanism for a formal vote if consensus is unreachable. ${ }^{138}$ That mechanism provides for double weighted voting, i.e., "an affirmative vote representing both a 60 percent majority of the total number of participants and a 60 percent majority of the total contributors." ${ }^{\text {"139 }}$ The GEF conveys its financing to developing countries through a range of intermediary and sub intermediary agencies, known under the GEF Instrument as "Implementing and . . . executing Agencies." "140 Only implementing agencies and executing agencies can submit project proposals for GEF Council approval. ${ }^{141}$

136. See id. para. 15, at 1287, para. 20, at 1288. An exception to the need for GEF Council grant approval applies to project preparation grants given to multilateral development banks that are approved by the Chief Executing Officer (CEO) of the GEF Secretariat. See Smyth, supra note 119, at 58. In addition to deciding on the GEF work program, the Council "monitor[s] the ongoing work program, review[s] the degree to which GEF activities conform to the priorities and policies of the relevant Conference of the Parties, oversee[s] the work of the Secretariat, review[s] and approv[es] the ... annual budget, and evaluat[es] GEF operational strategies, policies and programs.” Id. at 42 n.54 (citing David Freestone, The Establishment, Role and Evolution of the Global Environment Facility: Operationalising Common but Differentiated Responsibility?, in LAW OF THE SEA, EnVironmental LAW, AND SetTlement of Disputes: Liber Amicorum Judge ThOMAS A. MENSAH 1077, 1091 (Tafsir Malick Ndiaye \& Rüdiger Wolfrum eds., 2007)). The Council meets twice a year and more frequently as needed. GEF Instrument, supra note 109, para. 17, at 1288. Meetings are co-chaired by the CEO and a chair elected from among Council members for that purpose. Id. para. 18, at 1288 .

137. GEF Council, GLOBAL ENV'T FACILITY, http://www.thegef.org/gef/council (last visited Sept. 23, 2012). Of the GEF Council's thirty-two member countries, sixteen come from developing countries, fourteen come from developed countries, and two come from countries in "central and eastern Europe and the former Soviet Union.” GEF Instrument, supra note 109, para. 16, at 128788. The major contributors to the facility - France, Germany, Japan, the United Kingdom, and the United States-hold individual chairs on the Council. See Constituencies, Council Members and Alternates, GLOBAL ENV'T FACILITY, http://www.thegef.org/gef/Council_Members_Alternates (last visited Sept. 23, 2012). Other Council chairs represent constituencies of a number of members. See id.

138. Freestone, supra note 136, at 1090 (citing GEF Instrument, supra note 109, para. 25(c), at 1291).

139. GEF Instrument, supra note 109, para. 25(c)(i), at 1291.

140. See id. annex B, para. 4(b), at 1295. The GEF Instrument identifies the World Bank, UNDP, and the United Nations Environment Programme (UNEP) as implementing agencies. Id. para. 22, at 1290. Over the last several years, several entities, including all four of the regional multilateral development banks and a number of UN entities, have been approved to serve as executing agencies. GEF Executing Agencies, United NATIONS INDUS. DeV. ORG., http://www .unido.org/index.php?id=039564 (last visited Sept. 23, 2012). Proposals for the GEF Council to make direct grants to beneficiary countries are currently under review. See Direct Access for Enabling Activities (NPFE \& Convention Reports), GLOBAL ENV'T FACILITY, http://www.thegef .org/gef/EA_direct_access (last visited Sept. 23, 2012).

141. See Freestone, supra note 136, at 1097 (explaining GEF's “double approval system”). 
Member countries therefore exercise an active, ongoing role in shaping the strategy and priorities of international development institutions and in allocating those institutions' resources. Their delegation of power to institutional management is limited. In the face of this tendency, member states' mandate to include NGOs must be explicit. There is no basis on which to infer an implied mandate to these institutions to include NGOs in decision-making. As many scholars have noted, states create international institutions to serve their interests. ${ }^{142}$ The founding members' interests also determine such institutions' design. ${ }^{143}$ States' views of their interests and therefore of the purposes they want an institution to serve can change over time. ${ }^{144}$ Given these realities, the member states of international development institutions are likely to mandate NGO participation in institutional governance if and when they view such participation as necessary to the advancement of their institutional goals.

\section{F. Efficacy v. Credibility}

Therefore, the question raised by NGOs' pressure for NGO participation in the Green Climate Fund's governance ${ }^{145}$ and by observations of policy makers such as World Bank President Robert Zoellick and former UN Secretary-General Kofi Annan that NGO participation in institutional governance is critical to legitimacy, ${ }^{146}$ is not an issue of legitimacy. As Allen Buchanan and Robert Keohane point out, the implications of determining that an institution is illegitimate are

When the restructured GEF was first established, only the implementing agencies could submit project proposals for GEF Council approval. See Smyth, supra note 119, at 57. Executing agents, interested in securing GEF financing, had to submit their proposals through an implementing agency. See id. This process changed over time and executing agencies now enjoy equivalent status to implementing agencies. See id. at 60.

142. See, e.g., Barnett \& Finnemore, supra note 76, at 704 (noting that many scholars "treat [international organizations] as creations of states designed to further state interests”).

143. See Koremenos, Lipson \& Snidal, supra note 6, at 2 (positing that states construct and shape institutions to advance their goals).

144. See id. at 7 (stating that "institutional evolution... involves deliberate choices [by members] made in response to changing conditions").

145. See SIERRA, supra note 10, at 3.

146. See Zoellick, supra note 14, at 381 ("Modern multilateralism will not be a constricted club with more left outside the room than seated within. It will look more like the global sprawl of the Internet, interconnecting more and more countries, companies, individuals, and NGOs through a flexible network. Legitimate and effective multilateral institutions, backed by resources and capable of delivering results, can form an interconnecting tissue, reaching across the skeletal architecture of this dynamic, multi-polar system.”); Annan Press Release, supra note 15. 
significant. ${ }^{147}$ If an institution lacks legitimacy, "then [its] claims to authority [are] unfounded and [it is] not entitled to our support." ${ }^{, 148}$ In contrast, if an institution is legitimate but flawed, "the appropriate objective is to reform it, rather than to reject it outright." "As long as international development institutions operate within their memberimposed mandates, they will be legitimate whether or not they include NGOs in governance. The question, rather, is whether these institutions' member states should mandate NGO participation in institutional governance so as to make these institutions more credible and apparently worthy of our support. I address this question in Part III below.

\section{INTERNATIONAL DEVELOPMENT, CREDIBILITY, AND NGOS}

Those who advocate for the necessity of NGO participation in institutional governance maintain that NGO participation makes a development institution more credible because it enables the institution to be more effective. A firm showing of the impact of NGO participation in governance on an institution's credibility, effectiveness, or both would require empirical research that has not been done. Meanwhile, however, questions about the role to afford NGOs in new institutions, such as the Green Climate Fund, need an answer. Further, the need for change in institutions like the World Bank, where NGOs currently have little formal role, demands attention. For guidance on what should be done, we must draw on the views of scholars on the potential of NGOs to contribute to international institutions generally and on the lessons to be gleaned from case studies of recent practice in international development.

\section{A. The Inclusion v. Exclusion Debate}

Proponents of NGO participation in international institutions (inclusionists) maintain that NGOs ameliorate the pathologies of international institutions. ${ }^{150}$ They identify these pathologies as aloofness

\footnotetext{
147. Buchanan \& Keohane, supra note 62, at 407.

148. Id.

149. Id.

150. See, e.g., Charnovitz, supra note 1, at 894 (" $[T]$ he value-added from NGOs on the international plane is that they correct for the pathologies of governments and [international organizations].”); Charnovitz, supra note 48, at 271-74 (noting various aims of NGO participation including identifying deviations from policy and evaluating results); Spiro, supra note 1, at 169 (arguing that inclusion of NGOs in "institutional decisionmaking will ... advance the system
} 
from the real needs of real people, a lack of accountability to those people and to their member states, and a lack of transparency. ${ }^{151}$ The inclusionists see NGOs as solutions to these problems. The fact that NGOs operate on the ground level among the people most affected by international rulemaking gives them a hands-on expertise that most international bureaucracies lack. ${ }^{152}$ The inclusionists also point out that NGOs provide a high level of representatives for the issues and the unheard voices they serve. ${ }^{153}$ Unlike government representatives, NGOs cannot afford to fall out of touch with their constituents. ${ }^{154}$ Their very existence requires them to convey their constituents' views both at a national and an international level; if they fail to do so, their members will leave. ${ }^{155}$ Government representatives lack the same imperative to be responsive to their constituents, as constituents cannot easily relocate. ${ }^{156}$

Steve Charnovitz, one of the strongest proponents of inclusion, outlines the specific nature of NGOs' contributions to international institutional governance in a comprehensive work tracing NGO

itself"); Peter Spiro, NGOs and Human Rights: Channels of Power, in RESEARCH HANDBOOK ON HUMAN RigHTS LAW 115, 123-28 (Sarah Joseph ed., 2009) (describing types of interaction between NGOs and international organizations). In support of the importance of multi-stakeholder participation (including NGOs) in international environmental governance, see Jonas Ebbesson, Public Participation and Privatisation in Environmental Matters: An Assessment of the Aarhus Convention, 4 ERASMUS L. REV. 71, 88 (2011) ("Public participation matters ... for the legitimacy and effectiveness of environmental governance and decision-making.”); Kal Raustiala \& David G. Victor, Conclusions, in THE IMPLEMENTATION AND EFFECTIVENESS OF INTERNATIONAL ENVIRONMENTAL COMMITMENTS: THEORY AND PRACTICE 659, 667-68 (David G. Victor et al. eds., 1998) (noting NGOs' crucial role in environmental governance); Winfield J. Wilson, Feature, Legal Foundations for NGO Participation in Climate Treaty Negotiations, SustainABLE DeV. L. \& POL'Y, Winter 2010, at 54. In support of the importance of NGO participation in global health governance, see Jennifer Prah Ruger, Shared Health Governance, AM. J. BIOETHICS, July 2011, at 32; Devi Sridhar \& Lawrence O. Gostin, Reforming the World Health Organization, 305 JAMA 1585, 1585 (2011) (advocating that the World Health Organization give voice to and engage with NGOs).

151. See, e.g., Charnovitz, supra note 1, at 894-95, 902 (listing the benefits of NGO participation and noting that the cost to international organizations of allowing in NGOs will be increases in disclosure and transparency).

152. See, e.g., id. at 894 (noting how NGOs help recognize problems by "bringing in data and expertise”); Spiro, supra note 150, at 124-25 (noting the influence of NGOs and their consultative status in various UN bodies); Sridhar \& Gostin, supra note 150, at 1585 (implying the World Health Organization needs to work directly with communities in the world with health needs).

153. See, e.g., Spiro, supra note 1, at $165 \mathrm{n} .10$ (discussing NGOs giving minority elements a voice).

154. See id. at 164 (discussing how the multiplicity of issues confronted by legislative representatives allows them leeway to go against voter wishes).

155. See id. at 165 (contrasting the ease with which members can leave an NGO when displeased with the difficulty of exiting a state).

156. See id. at 164-65. 
participation in international governance from 1775 to the early 1990 s. $^{157}$ Charnovitz details core functions associated with institutional governance that NGOs are well-suited, and in some cases uniquely suited, to perform. ${ }^{158}$ These functions include gathering, analyzing, and disseminating information, advocating alternatives to decision makers, outing institutional failure to abide by their commitments, and serving as a catalyst for mobilizing action. ${ }^{159}$

As transnational actors, Charnovitz maintains, NGOs can help expose to public attention national rivalries serving as stumbling blocks to organizational consensus. ${ }^{160}$ NGOs can also "serve as competitors to international and national bureaucrats in [internal institutional] debates," and thereby ameliorate institutional insularity. ${ }^{161}$ Further, by "bringing in data and expertise to show that a problem exists," they can put pressure on institutional actors who might prefer to bury the problem. ${ }^{162}$ In addition, NGOs can usually fill in for failed states. ${ }^{163}$ Their individual passions will often cause them to "seek ... new rules that governments might not champion on their own." 164 Given NGOs' potential to make these multiple contributions, Charnovitz concludes that it is illegitimate to exclude their voice from international decision-making. ${ }^{165}$

157. Charnovitz, supra note 48, at 189-268.

158. See id. at 271 (citing Myres S. McDougal et al., The World Constitutive Process of Authoritative Decision, in INTERNATIONAL LAW ESSAYS: A SUPPLEMENT TO INTERNATIONAL LAW In Contemporary Practice 191, 219, 221-22, 267-69 (Myres S. McDougal \& W. Michael Reisman eds., 1981)).

159. See id. at 271-72.

160. See Charnovitz, supra note 1, at 894 (noting that "[s]tates seek to impose costs on other states and NGOs can counter such actions" through public exposure and argument).

161. See id. at 895 .

162. See id. at 894. Many NGOs are also viewed as tied in to the communities in which they operate. See PAUl J. NELSON, THE World BANK AND Non-GovernMENTAL ORGANIZATIONS: THE LiMITS OF APOLITICAL DEVELOPMENT 41 (1995). NGOs' role in supporting communities reflects three different styles: blueprint, broker, and process. Id. at 43 (citing DAVID D. Gow, LOCAL ORganizations and RuRAl DeVElopment: A Comparative Reappraisal (1979)). "The blueprint, adaptable to local conditions, offers an outline of technical or social changes-an irrigation system, latrines, etc.- that the NGO facilitates." Id. Broker NGOs serve as "intermediar[ies] between a community and regional or national government or an aid donor." Id. They help "the community develop plans and strategies to secure ... [what] the community wants." Id. A process style NGO, on the other hand, "focuses initially not on providing services or brokering relationships, but on facilitating a community's agreeing to goals and objectives, and to strategies for achieving them." Id. at 43-44.

163. See Charnovitz, supra note 1, at 894-95.

164. Id. at 895 .

165. See id. at 909-10. 
The potential contributions Charnovitz identifies are precisely the kind of functions NGOs perform in international development. ${ }^{166}$ The World Bank has acknowledged as much. ${ }^{167}$ Accordingly, Bank staff are encouraged to seek input from NGOs with expertise when formulating "policies, strategies, procedures, and major reports."168 NGOs also monitor and evaluate Bank projects, and the Bank has hailed them as "particularly effective in monitoring project impacts on indigenous peoples and the environment."169 In addition, Bank borrowers often engage NGOs in implementing projects, ${ }^{170}$ and a number of Bank grant programs include NGOs as eligible recipients. ${ }^{171}$

UNDP, likewise, publicly affirms that NGOs play a critical role in its work. It repeatedly refers to NGO participation as critical to the success of UNDP's objectives, ${ }^{172}$ and as a "duty and not an option for UNDP at all levels of its work."173 NGOs are involved in UNDP intelligence, advocacy, prescription, and monitoring functions. ${ }^{174}$ UNDP engages NGOs in country assessments, and its policies exhort "extending engagement beyond well-known organizations of civil society to... grass-roots organizations that are deeply embedded in the creative processes of societal change." ${ }^{175}$ UNDP also draws upon NGOs in translating the results of its annual Human Development Report into

166. See Jessica T. Mathews, Power Shift, 76 FOREIGN AFF. 50, 53 (1997) (noting that NGOs "breed new ideas; advocate, protest, and mobilize public support; do legal, scientific, technical, and policy analysis; provide services; shape, implement, monitor, and enforce ... commitments; and change institutions and norms”); Spar \& Dail, supra note 5, at 175 (listing various focuses of NGOs).

167. WBGP 14.70, supra note 52, para. 6(a)-(h).

168. Id. para. 11.

169. Id. para. 22.

170. Id. para. 26.

171. Id. para. 23. For a full account of Bank grant programs, see Sophie Smyth, World Bank Grants in a Changed World Order: How Do We Referee This New Paradigm?, 30 U. PA. J. INT'L L. 483 (2008).

172. See UNDP Engagement with Civil Society, United NATIONS DEV. Programme, http://www.undp.org/content/undp/en/home/ourwork/partners/civil_society_organizations.html (last visited Sept. 24, 2012) (describing UNDP's engagement with civil society as “critical to ... the quality and relevance of official development programmes”); UNITED NATIONS DEV. PROGRAMME, UNDP AND Civil Society ORganizATIOns: A PRACTiCE Note On ENGagement para. 1 (2001) [hereinafter UNDP ENGAGEMENT NOTE], available at www.undp.org/content/undp/en/home/library page/democratic-governance/civic_engagement/undp-and-civil-society-organizations-a-policy-ofengagement-2001.html (stating that "the UNDP focus on sustainable human development that places people at the centre of development cannot be achieved without the robust engagement of civil society and its organizations”).

173. UNDP ENGAGEMENT NOTE, supra note 172, para. 25.

174. See id. para. 37 (describing how NGOs assist UNDP projects).

175. Id. paras. 37-38. 
"advocacy strategies and campaigns for effecting policy changes," and in monitoring countries' progress on the Millennium Development Goals. ${ }^{176}$

UNDP's approach to NGO participation is driven by its commitment to the view that development is a human right. ${ }^{177}$ Its policies reflect an intention to establish formal means to listen to individuals in developing countries, and it relies on local NGOs to help deliver on that goal. ${ }^{178}$ Further, while recognizing its obligations towards governments, UNDP also explicitly acknowledges an obligation to respect civil society's rights. ${ }^{179}$ In maintaining that it bears "duties and obligations towards the poor," UNDP acknowledges that it needs to "engage with and involve a range of civic actors" to fulfill those obligations. ${ }^{180}$

NGOs are thus deeply involved in international development. In addition, the World Bank and UNDP acknowledge that NGOs are indispensable. ${ }^{181}$ The case for some degree of NGO participation in all development institution decision-making is strong. In fact, however, as detailed below, such participation is not the norm. What then, is the reason for their exclusion?

The case for exclusion has several sources. The exclusionists come in two flavors representing different ends of the critique of Westphalian sovereignty. ${ }^{182}$ At one end are the international realists who deny that anyone but sovereign states ought to have a role in international affairs. ${ }^{183}$ Far from seeing NGO participation as enhancing institutions, they view such participation as an illegitimate intrusion on sovereignty. ${ }^{184}$ This view of state supremacy gives rise to vehement opposition to sovereign states deigning to share decision-making power

176. Id. para. 37.

177. See id. at 5 box 2 (noting that exclusion of certain groups from the benefits of development is a human rights abuse).

178. See id. para. 23.

179. Id. para. 17.

180. Id. para. 7.

181. See supra notes $167-80$ and accompanying text.

182. "Westphalian sovereignty refers to political organization based on the exclusion of external actors from authority structures within a given territory." STEPHEN D. KRASNER, SOVEREIGNTY: ORGANIZED HYPOCRISY 3-4 (1999).

183. See, e.g., Jeremy RABKin, Why Sovereignty MatTers 41-42 (1998) (noting the increasing role of NGOs in international affairs and lamenting NGOs' transfer of "deliberations from the U.S. political system" to outside venues); Jeremy Rabkin, International Law vs. the American Constitution-Something's Got to Give, 55 NAT'L INT. 30, 37 (1999) (criticizing international institutions interfering with governments and the concept of "global civil society").

184. See Spiro, supra note 1, at 162 ("Some who question NGO legitimacy would simply wish a return to the old world in which states aggregately held most associational power.”). 
over matters of global governance with nonstate entities such as NGOs. ${ }^{185}$

At a primal level, the realists' argument is based on a view of international affairs that places the state at the center of world politics. ${ }^{186}$ This view holds that world politics is a "two-level game, with domestic political preferences as a variable in interstate relations." ${ }^{\text {"187 }}$ According to this view, states should "remain dominant in the establishment of formal international regimes" and NGOs' role is to apply pressure on states in the domestic political sphere. ${ }^{188}$ States may then, if they so choose, represent the NGOs' viewpoints in the international sphere. ${ }^{189}$

At the other end of the exclusionist spectrum is a group that has no truck with Westphalian sovereignty. Instead, their objection to NGO participation stems from their view of NGOs as either captive vassals of state organizations $^{190}$ or as unrepresentative special interest groups reflecting the desires of a nonrepresentative elite portion of society. ${ }^{191}$ We can think of this latter group as the civil society skeptics. They are willing to tear down the barriers of Westphalian sovereignty but do not believe NGOs are democratically legitimate. ${ }^{192}$ This view is often summed up in the pithy query, "Who elected the NGOs?"193

The skeptics' view is based on a deep distrust of the representativeness of NGOs and therefore of their authority to speak on

185. See id.

186. See Peter J. Spiro, Non-Governmental Organizations and Civil Society, in THE OXFORD HANDBOOK OF INTERNATIONAL ENVIRONMENTAL LAW 770, 770 (Daniel Bodansky et al. eds., 2007) (noting NGOs were marginalized during the Cold War due to state-centric views of international decision-making).

187. Id. at 775 (citing Robert Putnam, Diplomacy and Domestic Politics: The Logic of Two Level Games, 42 INT’L ORG. 427 (1988)).

188. Id. at 776 .

189. See id.

190. See, e.g., Kenneth Anderson, The Ottawa Convention Banning Landmines, the Role of International Non-governmental Organizations and the Idea of International Civil Society, 11 EUR. J. INT'L L. 91, 112 (2000) (describing the intertwining of states and NGOs).

191. See, e.g., id. at 118 (criticizing the democratic legitimacy of international NGOs that act "not [as] conduits from the 'people' or the 'masses' or the 'world citizenry' from the 'bottom up'," but, rather, as "vehicle[s] for international elites" to pursue their own agendas); Kenneth Anderson, "Accountability" as "Legitimacy": Global Governance, Global Civil Society and the United Nations, 36 BROOK. J. INT’L L. 841, 868 (2011) (noting that civil society is not representative).

192. See, e.g., Anderson, supra note 190, at 120 (stating that the Ottawa Convention banning land mines was a good development, but the NGOs that helped bring it about were not democratically legitimate).

193. Id. at 119 (quoting David Rieff, Panel Discussion on Landmines and International Civil Society at Washington College of Law, American University (Feb. 25, 1998)) (internal quotation marks omitted). 
[Vol. 61

behalf of ordinary citizens on a par with states. ${ }^{194}$ Largely, this view is based on opposition to a premise that sweeps all NGO participation in international institutional decision-making under the too-broad umbrella of global governance by a putative global civil society. ${ }^{195}$ According to that view, globalization requires a global government. ${ }^{196}$ In truth, however, supporting NGO participation in the governance of an international development institution is several degrees removed from embracing the idea of a global government exerting global lawmaking authority. ${ }^{197}$

Opposition to including NGOs in institutional decision-making also stems from the paymaster principle. Donor states that contribute the largest amounts to international development institutions want the largest say in those institutions' decisions and are reluctant to share control of their contributed resources with states that contribute less. ${ }^{198}$ In the same vein, donor states shy from sharing control over those resources with non-contributors, such as NGOs, that generally do not donate resources. ${ }^{199}$

194. See, e.g., Anderson, supra note 191, at 868 (noting that a ballot box is an intermediary between citizens and the government and no such analogue exists between citizens and NGOs); Ruth W. Grant \& Robert O. Keohane, Accountability and Abuses of Power in World Politics, 99 AM. POL. SCI. REV. 29, 38 (2005) (noting that because "NGOs are typically the result of entrepreneurial initiatives by activists[,] . . they do not result from a process of delegation"). Note, opponents of the view that NGOs should be excluded from global governance do not dispute that exclusionists make some valid claims. See, e.g., Spiro, supra note 1, at 162 ("Wherever power is exercised, questions of accountability are appropriately posed." (citing Peter J. Spiro, New Global Communities: Nongovernmental Organizations in International Decision-Making Institutions, WASH. Q., Winter 1995, at 45; Peter J. Spiro, New Global Potentates: Nongovernmental Organizations and the "Unregulated" Marketplace, 18 CARDOZO L. REV. 957 (1996))). They argue, however, that inclusion with safeguards is a more informed and fruitful way to address valid concerns about representativeness. See, e.g., id. (arguing that "[f]ormal NGO participation in international decisionmaking would have the effect of outing NGO power" and holding NGOs accountable).

195. See, e.g., Anderson, supra note 191, at 845 (discussing NGO participation in the context of an overarching question on the feasibility and desirability of "global governance").

196. See Bodanksy, supra note 17, at 623 (noting that globalization has strained the system and international governance is needed to address environmental problems that individual states cannot).

197. See Anderson \& Rieff, supra note 1, at 26 (challenging the idea of global civil society and offering alternate ways of understanding NGOs, including as an analogue to earlier missionary movements). Anderson and Rieff concede, however, that international NGOs' original claim to a right to be respectfully heard by those engaged in international planning and execution of policy commands respect. Id. at 35. For proponents of the idea of a global government, see, for example, DAVID Held, DEMOCRACy AND THE Global ORDER: From the MOdern State tO COSMOPOLITAN GOVERNANCE 273-74 (1995) (advocating the idea of a global government through the establishment of a directly elected "independent assembly of democratic peoples").

198. See supra Part II.E.

199. See supra Part II.E. 
Additionally, at a purely pragmatic level, inclusiveness is timeconsuming and expensive. ${ }^{200}$ Even when individual member countries support inclusion, institutional opposition is predictable. ${ }^{201}$ NGO participation makes life difficult for an institution and disrupts the cozy internal status quo. ${ }^{202}$ NGO participation is likely to cause pressure to make policy changes, increase disclosure and transparency needs, and cabin institutional discretion. ${ }^{203}$ Moreover, the costs of providing processes to allow for NGO participation are likely considerable. ${ }^{204}$ For all of these reasons, the concept of NGO participation meets resistance and generates fear and aversion in governments and international institutions, including international development institutions. Whether and to what degree NGOs are allowed to participate in governance becomes a push and pull of these competing interests.

\section{B. Lessons From the Field}

As indicated above, states' views on whether NGO participation in the governance of international development institutions advances the states' interests will vary across institutions and over time. ${ }^{205}$ In the creation of sector-specific institutions like the GEF and the Global Fund, states have veered towards inclusion. That tendency counters the tendency towards exclusion that preceded it and that still applies to the World Bank and the UN. ${ }^{206}$ The contrast between states' practice in these two categories of development institutions prompts consideration of the reasons why these different generations and types of international

200. See Charnovitz, supra note 1, at 902 (noting a cost of allowing NGO participation to international organizations is increased disclosure and transparency (citing Laurence Boisson de Chazournes, Changing Roles of International Organizations: Global Administrative Law and the Interplay of Legitimacies, 6 INT'L ORG. L. REV. 655, 660 (2009))).

201. See KARNS \& MINGST, supra note 48, at 230 (noting that some intergovernmental organizations have continually ignored NGOs' demands to participate); Brakman Reiser \& Kelly, supra note 33, at 1071-73 (discussing costs of “accreditation, monitoring, and enforcement mechanisms”).

202. See Charnovitz, supra note 1, at 902-03 (describing ways an NGO might agitate for internal change).

203. Id.

204. Brakman Reiser \& Kelly, supra note 33, at 1071-72 (noting that the costs of establishing and implementing procedures for allowing NGO participation can be considerable and suggesting ways of reducing these costs).

205. See supra Part II.E.

206. See Gartner, supra note 22, at 599 (noting that states formerly managed governance of international institutions to the exclusion of nongovernmental entities). 
development institutions persist with different norms, and of how or whether the difference might affect their respective credibility.

\section{The Inclusion Norm}

Starting in the early 1990s, NGOs adopted a new approach to securing increased participation in international development. Instead of limiting themselves to advocating for a greater role in established institutions like the World Bank and the UN, they urged donor states to pursue international development through alternative channels: specialized funds dedicated to providing development assistance in specific, narrowly defined sectors. ${ }^{207}$ I refer to these funds as "special purpose funds." The GEF, Global Fund, and the Green Climate Fund are prime examples.

NGOs pressed for the special purpose fund approach because it offers new opportunities for NGOs. Each fund is a tabula rasa with a governance structure that donors can design and customize to meet their needs. ${ }^{208}$ The newness of a fund's structure allows for more flexibility than a preexisting institution with a long history of doing business as a government-only club. ${ }^{209}$ This newness and flexibility opens the door for NGOs to press for a governance structure that incorporates them. Not surprisingly, these funds have a strong norm of inclusion.

The special purpose fund phenomenon and the attendant norm of inclusion began with the creation of the GEF in $1994 .^{210}$ The norm of inclusion reached new heights with the creation of the Global Fund in 2002. ${ }^{211}$ Both of these funds include NGOs in governance to a degree

207. See, e.g., Charlotte Streck, The Global Environment Facility-A Role Model for International Governance?, GLOBAL ENVTL. POL., May 2001, at 71, 86 ("NGOs played a strong and important role during the foundation of the GEF.”); Sonja Bartsch, The Global Fund to Fight AIDS, Tuberculosis and Malaria: Establishment, Current Issues and Future Challenges 4-5 (2005) (paper presented at the Salzburg Seminar on the Governance of Health (Dec. 5-8, 2005)), available at http://www.temple.edu/lawschool/phrhcs/Salzburg/Bartsch_Global_Fund.pdf (noting how a "strong coalition of NGOs" with health-related focuses pushed for the Global Fund as well as for participation in its governance).

208. See, e.g., Bartsch, supra note 207, at 5 (discussing how NGOs were successful in influencing the governance structure of the Global Fund, securing rights to consult as well as decision-making power). As David Gartner has noted, if an institution is not designed to be inclusive of NGOs, "opportunities for transformation of governance... may be quite limited." Gartner, supra note 22, at 639.

209. See KARNS \& MINGST, supra note 48, at 235-37 (describing NGOs’ efforts to influence and gain access to institutions including the World Bank, IMF, and the World Trade Organization).

210. What is the GEF, supra note 120 (discussing the history of the GEF).

211. Who We Are, GLOBAL FUnd TO FIGHT AIDS, TUBERCUlosis \& MALARIA, 
that was unprecedented before their creation. ${ }^{212}$ As precedents, they offer two competing models for NGO participation in governance. For ease of reference, I label these competing models the "active observer" model (which emerged and evolved in the GEF) and "the coequal decision-maker model” (which emerged in the Global Fund).

\section{a. NGOs As Active Observers}

The active observer model emerged from the GEF, which was partially the brainchild of international environmental NGOs. ${ }^{213}$ The GEF's creation was a path-breaking triumph for NGO activism. ${ }^{214}$ One of the first initiatives the GEF Council undertook was to formalize a process of consulting with NGOs. In its second meeting, the GEF Council decided that ten NGOs should be allowed to participate at each Council meeting, five as "attendees" and five as "observers." 215 Attendees would be present at Council meetings and have the right to participate in discussions before the Council but not discussions in executive session - which primarily concerned the GEF's administrative budget and amendments to its rules of procedure. ${ }^{216}$ Observers would

http://www.theglobalfund.org/en/about/whoweare/ (last visited Sept. 25, 2012) (discussing the history of the Global Fund).

212. See nata Duvvury et al., InT’L Ctr. For Research on Women, Participation of CIVIL SOCIETY IN GLOBAL GOVERNANCE: LESSONS LEARNED FROM THE GLOBAL FUND TO FIGHT HIV/AIDS, TUBERCULOSIS AND MALARIA 9 (2005), http://www.icrw.org/publications/ParticipationCivil-Society-Global-Governance-Lessons-Learned-from-the-Global-Fund-to-Fight-HIV-AIDS-

Tuberculosis-and-Malaria.pdf (describing civil society's participation in governance of the Global Fund as "pioneering”); Streck, supra note 207, at 89 (describing the governance model of the GEF as "quite unusual").

213. See Streck, supra note 207, at 75-76 (describing NGOs' dissatisfaction with the GEF's precursor and their role in restructuring the GEF).

214. See id. at 86 (noting the important role NGOs had in the creation of the GEF and thereafter). The Conventions on Climate Change and Biodiversity were a hard sell and especially unpopular among developing countries that viewed them as unfair impediments to their process of industrialization imposed by developed countries that themselves industrialized and became wealthy without paying heed to the environment. See United NATIONS, United NATIONS FrameWORK Convention on Climate Change: The First Ten Years 13-14 (2004), http://www.unfccc.int/resource/docs/publications/first_ten_years_en.pdf (describing the negotiation process for the UNFCCC). The financing the GEF promised was key to securing developing countries' support. See id. at 14. The GEF began in 1991 as a pilot initiative, the Global Environment Trust, which was later restructured and renamed the GEF. Streck, supra note 207, at 72-76 (outlining the beginnings of the GEF).

215. GEF, Criteria for Selection of NGOs to Attend/Observe Council Meetings and Information on NGO Consultations, annex A, GEF/C.3/5 (Feb. 22-24, 1995), http://www.thegef.org/gef/sites/ thegef.org/files/documents/GEF.C.3.5.pdf [hereinafter Criteria for Selection of NGOs].

216. Id. 
follow the meeting on closed-circuit television. ${ }^{217}$ The Council also allocated funds to defray the cost of NGOs' attendance. ${ }^{218}$ The Council's manifest commitment to NGO engagement was groundbreaking.

Delivering on the Council's commitment, however, presented challenges. Providing for the participation of ten NGOs begged the question of what NGOs should be so anointed. ${ }^{219}$ It also generated related questions about what criteria should be used to select the participating NGOs and who should decide whether the criteria had been met. ${ }^{20}$ Further, as the universe of eligible NGOs far exceeded ten, decisions were required on whether the right to participate should rotate among them and, if so, how frequently. ${ }^{221}$

Over time, the GEF answered these questions, and those answers evolved. From early ad hoc decisions, a highly formalized state-of-theart systematic process emerged to regulate the representativeness, transparency, and accountability of NGO input in GEF decisionmaking. ${ }^{222}$ The GEF Secretariat initially proposed that it would select the NGOs to serve as attendees and observers and also devised selection criteria, subject to the Council's approval. ${ }^{223}$

The selection criteria require that the ten NGOs selected to attend Council meetings be diverse in the views and geographic areas they represent, and be balanced among international, national, and local groups. ${ }^{224}$ Further, the criteria generally give preference to NGOs whose organizational perspectives are broad-based. ${ }^{225}$ The applicable Council agenda may justify filling more attendee and observer positions with NGOs possessing particularized expertise or perspectives. ${ }^{226}$ Also relevant is the attendance of NGOs at previous Council meetings; rotation is encouraged. ${ }^{227}$

The task of selecting NGOs was lightened because NGOs interested in GEF matters became accustomed to coordinating with each other

217. History of the GEF NGO Network, GEF-NGO NETWORK, http://www.gefngo.org/ index.cfm?\&menuid=75 (last visited Sept. 26, 2012).

218. Criteria for Selection of NGOs, supra note 215, annex A.

219. See id. para. 2.

220. Id.

221. See id. para. 12.

222. See History of the GEF NGO Network, supra note 217.

223. See Criteria for Selection of NGOs, supra note 215, paras. 2, 7.

224. Id. paras. 9, 11.

225. Id. para. 11 .

226. Id.

227. Id. 
during the GET, the pilot phase of the GEF. ${ }^{228}$ These NGOs developed a practice of presenting their shared concerns to the GET Participant's Committee a day or two prior to the Participant Committee's meetings. ${ }^{229}$ NGOs carried this tradition over to the restructured GEF. ${ }^{230}$ The NGO community interested in GEF matters formed itself into a GEF-NGO Network, seizing the opportunity to attend Council meetings. ${ }^{231}$ The Secretariat drew on the Network to select the NGOs that would attend a given Council meeting. ${ }^{232}$ Network members were invited to apply to the GEF Secretariat to be accredited as eligible for one of the ten slots. ${ }^{233}$ The Secretariat liberally granted accreditation provided the NGO met fairly minimal criteria set by the Secretariat and approved by the Council. $^{234}$ Formal NGO participation in GEF Council meetings thus became a fixture of GEF governance early in the GEF's existence. ${ }^{235}$

228. See History of the GEF NGO Network, supra note 217 (describing NGOs' activities in the GEF pilot phase).

229. David Reed, The Global Environment Facility and Non-Governmental Organizations, 9 AM. U. J. INT'L L. \& POL’Y 191, 206 (1993).

230. See History of the GEF NGO Network, supra note 217 (discussing the creation of a more formalized NGO consultation process).

231. Id.

232. Id.

233. Criteria for Selection of NGOs, supra note 215, annex B.

234. See id. The GEF defines an NGO as a "non-profit organization[] whose mandate, experience, expertise and capacity are relevant to the work of the GEF, including: community groups; local, national, regional and international organizations, including NGO networks, dedicated to preserving the environment or promoting sustainable development; indigenous people's organizations; and academic and research institutions.” Id. para. 5.

235. This participation has been identified as substantive. See Bleaney \& SAINT-LaURENT, supra note 20, annex 2, at 40 . That NGO participation in Council meetings is actually the last step of a continuing GEF-NGO dialogue that takes place before Council meetings may be one reason why NGO representation at Council meetings is substantive. See id. The GEF Council mandated this continuing dialogue when it instituted NGO participation in the Council. See GEF, Joint Summary of the Chairs, GEF Council Meeting, February 22-24, 1995, para. 14, GEF/C.3/JointSummary (Feb. 28, 1995), http://www.thegef.org/gef/sites/thegef.org/files/documents/ GEF.C.3.JointSummary.pdf [hereinafter Joint Summary of the Chairs 1995] (noting that a majority of Council members thought the NGO consultations prior to Council meetings were useful). The Council's decision was clear that NGO participation in Council meetings would supplement but not replace the GEF-NGO consultation process that began during the pilot phase. The Council instructed the Secretariat to continue to convene semiannual NGO consultations in conjunction with the Council's regular meetings. See id. Further, the Secretariat suggested there should be one regional consultation with NGOs on an annual basis, independent of the Council meetings that could rotate among different regions. Criteria for Selection of NGOs, supra note 215, para. 20.

"For NGO representatives, the [GEF] Council meeting is the final of a series of three meetings held twice a year over the course of one week." BLEANEY \& SAINT-LAURENT, supra note 20, annex 2, at 40 . The GEF-NGO Network now routinely convenes an NGO preparatory meeting two days before each Council meeting. Id. Exclusively attended by NGOs, the preparatory meeting is an entire day “dedicated to preparing NGOs' views and positions." Id. 
As the GEF grew and the universe of interested NGOs expanded, the interaction between the GEF-NGO Network and the GEF became the target of criticism. ${ }^{236}$ In response, the Council decided to delegate the NGO accreditation process to NGOs themselves. ${ }^{237}$ In 2008, it terminated the GEF Secretariat's NGO accreditation powers. ${ }^{238}$ Instead, the Council decided that membership of the GEF-NGO Network should be the conduit for accreditation of NGOs to the GEF. ${ }^{239}$ NGOs themselves would select what NGOs would attend Council meetings. ${ }^{240}$

Since then, a formal structure for the GEF-NGO Network has emerged that is coordinated by a committee designated by the GEF-NGO Network, the Coordination Committee, subject to defined rules. ${ }^{241}$ These rules prescribe an extraordinary level of diversity in the NGO representatives. $^{242}$ In June 2010, as part of a campaign to achieve more

The meeting is followed by the Council-prescribed GEF-NGO Consultation, which is "jointly organized and co-chaired by the Chair of the GEF NGO Network and the GEF Secretariat." Id. The Council Meeting agenda, which is posted several weeks in advance, drives the Consultation agenda. Id. Representatives of implementing agencies and executing agencies also attend the NGO Consultation, and Council members are also invited. Id. "NGOs voice concerns, comment on policies and projects and present positions on substantive issues." Id.

236. GEF, Review of the Non-Governmental Organization Network of the GEF, paras. 120-29, GEF/C.27/Inf.5 (Oct. 24, 2005), available at http://www.thegef.org/gef/node/550 (noting problems with the NGO Network and the GEF's model of NGO participation); GLOBAL ENV'T FACILITY, OPS3: PROgREssing TOWARD ENVIRONMENTAL REsUlts $\S 6.2 .7$ (2005), available at www.the gef.org/gef/OPS3 (same).

237. See GEF, Joint Summary of the Chairs, GEF Council Meeting, November 11-13, 2008, para. 28, GEF/C.34/JOINTSUMMARY (Nov. 17, 2008), http://www.thegef.org/gef/sites/thegef.org/ files/documents/Joint\%20Summary\%20of\%20the\%20Chairs_C.34.pdf.

238. See id.

239. Id. This decision flowed from the findings of the Secretariat's review of the accreditation process: the process was ineffectively cumbersome, the Secretariat lacked the information needed to review accreditation requests, and there was no process for periodically reviewing accreditation status. GEF, Enhancing Civil Society Engagement and Partnership with the GEF, para. 21(a), GEF/C.34/9 (Oct. 14, 2008) [hereinafter GEF, Enhancing Civil Society Engagement], available at http://www.thegef.org/gef/node/243.

240. Joint Summary of the Chairs 1995, supra note 235, para. 13.

241. See Roles \& TOR of the Coordinating Committee, GEF-NGO NETwORK, http://www. gefngo.org/index.cfm?\&menuid=118\&parentid=13 (last visited Sept. 27, 2012) (describing the leadership role of the coordination committee).

242. See GEF-NGO NETWORK REVISED Rules, supra note 49, § 2.2.3, annex 1 (mandating election of representatives from sixteen regions encompassing six continents). The Network's expanded responsibilities came after it worked with the Secretariat to develop a clear governance structure with rules and procedures for operation. See GEF, Enhancing Civil Society Engagement, supra note 239, para. 3. The Network now has 487 members. Members, GEF-NGO NETWORK, http://www.gefngo.org/formmaster.cfm?\&action=main\&menuid=12 (last visited Sept. 27, 2012). Current regional focal points (RFPs) include organizations such as the Mauritius Council of Social Service (MACOSS) for the Eastern Africa region, the Caribbean Forest Conservation Association (CFCA) for the Caribbean region, and the Caucasus Environmental NGO Network (CENN) for the Eastern Europe and Central Asia region. GEF-NGO NETWORK, CURRENT GEF NGO NETWORK 
involvement for NGOs in the GEF, the Network tightened its criteria for membership and instituted a rule that membership in the Network expires unless it is renewed every three years. ${ }^{243}$

NGO demands for a role in GEF governance continue to expand. NGOs sought and secured access to the triannual GEF Assembly meetings. ${ }^{244}$ NGO representatives have addressed the Assembly at recent meetings. ${ }^{245}$ Further, the GEF-NGO Network held a Civil Society Forum prior to the Assembly Meeting in 2010. ${ }^{246}$ NGOs have also recently secured the right to serve as direct intermediaries of GEF financing. ${ }^{247}$ Such eligibility means that NGOs may submit proposals for GEF financing to the Council, ${ }^{248}$ a right reserved until recently to the World Bank, the regional development banks, and a list of specified UN agencies. $^{249}$

Regional Focal Points (ORganisations) And RELAted RePRESENTATIVES (April 2012), available at http://www.gefngo.org/index.cfm?\&menuid=34 (follow "For a complete list of the Regional Focal Points, please click here" hyperlink). Each region conducts its own election to choose its RFP. GEF-NGO NETWORK REVISED RULES, supra note 49, § 2.2.3. The Coordination Committee then elects a Central Focal Point. Id. § 2.2.5. Examples of U.S. NGOs that are members of the Network include: American Forests, the Global Coral Reef Alliance, the Nature Conservancy, the National Audubon Society, and the World Wildlife Fund. Members, supra.

243. GEF-NGO NETWORK REVISED RULES, supra note 49, annex 9, at 34.

244. See Why Be a Network Member?, GEF-NGO NETWORK, http://www.gefngo.org/index. cfm?\&menuid=71 (last visited Sept. 27, 2012).

245. See Assembly, GLOBAL ENV'T FACILITY, http://www.thegef.org/gef/assembly (last visited Sept. 27, 2012). NGO representatives have attended all four of the General Assembly meetings that have been held to date. See GEF, Chair's Summary of the Fourth GEF Assembly, para. 17, GEF/A.4/Summary (May 26, 2010), available at http://www.thegef.org/gef/node/3212; A Brief History of the GEF, GEF-NGO NETWORK, http://www.gefngo.org/index.cfm?\&menuid=66 (last visited Sept. 27, 2012).

246. Civil Society Forum, GEF-NGO NETWORK, http://www.gefngo.org/index.cfm?\&menuid= 140 (last visited Sept. 27, 2012).

247. See Accreditation of GEF Project Agencies, GLOBAL EnV'T FACILITY, http://www.thegef.org/gef/agencies_accreditation (last visited Sept. 27, 2012) (“[N]ew agencies to be accredited ... will be referred to as GEF Project Agencies... [and] will [be able] to access resources from GEF-managed trust funds directly.”).

248. See GEF Agencies, GLOBAL ENV’T FACILITY, http://www.thegef.org/gef/gef_agencies (last visited Sept. 27, 2012) (noting that current GEF agencies create project proposals).

249. See Smyth, supra note 37, at 1026; GEF Agencies, supra note 248. NGOs eligible to serve as direct intermediaries will be selected by a GEF Accreditation Panel, a new body appointed to accredit a range of entities, including NGOs, to serve as GEF Project Agencies. See GEF, Broadening the GEF Partnership Under Paragraph 28 of the GEF Instrument, paras. 11-12, GEF/C.40/09 (Apr. 26, 2011), http://www.thegef.org/gef/sites/thegef.org/files/documents/C.40. 09_Broadening_the_GEF_Partnership.04_26_11.pdf (describing the accreditation procedure). Previously, the only grants NGOs could secure directly from the GEF were small grants (up to a maximum of $\$ 50,000$ ) under the GEF Small Grants Programme, designed to encourage local communities and NGOs to participate in furthering the GEF's goals. See Mission and History, GEF SMALL GRANTS PROGRAMME, http://www.sgp.undp.org/index.php?option=com_content\&view= article\&id=98\&Itemid=156 (last visited Sept. 28, 2012). 
NGOs are now pressing for formal NGO representation in GEF replenishment meetings, ${ }^{250}$ which take place every four years. ${ }^{251}$ Inevitably, these meetings become a forum for donors to assert their objectives for the GEF. ${ }^{252}$ NGOs therefore have a strong interest in having a voice in this dialogue, where recommendations for future GEF policy are formulated and proposed. To date, NGOs have only had observer status at GEF replenishment meetings. ${ }^{253}$ Their demand for a more formalized role, which includes a request for the GEF to "organise national and regional consultations on replenishment,"254 similar to the consultations held in connection with GEF Council Meetings, has not been granted.

As updated and refined from the original version, the active observer model of NGO participation now consists of the following: presence at the meetings of the loci of power; the right to participate in issues under discussion, exclusive of executive sessions; and pre-meeting meetings and continual contact to allow participation to be meaningful. This model has since become a precedent for other initiatives. It was adopted by the creators of the Climate Investment Funds in 2008, which are two funds created to finance developing countries' efforts to combat climate change ${ }^{255}$ in preparation for international agreement on a global climate change strategy for 2012 and beyond. ${ }^{256}$

250. GEF-NGO NETWORK, Civil SOCIETY EXPECTATIONS FOR THE FIFTH REPLENISHMENT: SuMMARY STATEMENT 2 (June 22, 2009) [hereinafter Civil SOCIETY EXPECTATIONS], available at http://www.gefngo.org/index.cfm?\&menuid=87\&parentid=109 (follow "Civil Society Expectations for the Fifth Replenishment-Summary Statement 22 June 2009—Doc 44KB” hyperlink).

251. GEF Replenishments, GLOBAL ENV’T FACILITY, http://www.thegef.org/gef/replenishment (last visited Sept. 29, 2012).

252. See id. (noting that attendees negotiate and agree on a GEF programming guide). Frequently, individual donors condition their willingness to contribute to replenishment on the GEF's agreeing to pursue that donor's vision of what the GEF's agenda should be. For example, the United States conditioned its contribution to the fourth GEF replenishment on the GEF's adopting a Resource Allocation Framework. See Raymond Clémençon, What Future for the Global Environment Facility?, 15 J. ENV'T \& DEV. 50, 59 (2006). Typically, donors will outline policy proposals at replenishment meetings that are then compiled and forwarded to the GEF Council for approval as part of a replenishment package. See GEF Replenishments, supra note 251; see also Smyth, supra, note 119, at 55 (noting that "policy recommendations would come to dominate the [replenishment] negotiations”).

253. GEF, Summary of Negotiations: Fifth Replenishment of the GEF Trust Fund, para. 5, GEF/A.4/7 (May 17, 2010), available at http://www.thegef.org/gef/4th_assembly_summary_ negotiation.

254. CIVIL SOCIETY EXPECTATIONS, supra note 250, at 2.

255. See History, Climate INVESTMENT FUnDS, http://www.climateinvestmentfunds.org/cif/ designprocess (last visited Sept. 29, 2012).

256. Richard G. Lugar \& Henry M. Paulson Jr., Op-Ed., Bridging the Gap on Climate Change, WASH. POST, July 14, 2008, http://www.washingtonpost.com/wp-dyn/content/article/2008/07/13/AR 
Similar to the role NGOs have gained in the GEF, NGOs participate as active observers in the governing bodies of these funds, known as Trust Fund Committees (TFCs). ${ }^{257}$ The NGO representatives to the Clean Technology Fund are drawn from a diverse and representative group of observers including "NGOs, development and environment institutions and 'think tanks,' local communities and indigenous peoples groups." 258 The Strategic Climate Fund invites four CSO representatives, two Indigenous Peoples representatives, two private sector representatives, and representatives from the GEF, UNFCCC, UNDP, and UNEP. ${ }^{259}$ Most recently, the creators of the Green Climate Fund have selected the active observer model as their model of choice. ${ }^{260}$

\section{b. NGOs As Coequal Decision-Makers}

The founders of the Global Fund took the leap that neither the GEF nor any other development institution had taken and included NGOs as voting members in its governing bodies. The Fund thereby introduced a

2008071301723.html; Marianne Lavelle, What's Behind Bush's Clean-Technology Fund, U.S. NEWS \& WORLD REP.: MONEY (Jan. 29, 2008), http://www.usnews.com/blogs/beyond-thebarrel/2008/01/29/whats-behind-bushs-clean-technology-fund. While one might have expected the GEF to step into that role, the United States likely wanted an entity more easily controlled by it and other developed countries. See William Gardner, Note, The Fight for Clean Technology Funds: Who Should Control the Future of Low-Carbon Technology in the Developing World?, 18 IND. J. Global Legal STUD. 481, 492 (2011) (noting the United States' influence over the World Bank and concluding the Clean Technology Fund's "procedures do, in fact, favor developed countries").

257. The World Bank, Strategic Climate Fund para. 27 (June 3, 2008), http://www. climateinvestmentfunds.org/cif/sites/climateinvestmentfunds.org/files/Strategic_Climate_Fund_final .pdf; CTF Observers, CLIMATE INVESTMENT FUnDS, http://www.climateinvestmentfunds.org/ cif/CTF_Observers (last visited Sept. 29, 2012); SCF Observers, ClimATE INVESTMENT FunDS, http://www.climateinvestmentfunds.org/cif/SCF_Observers (last visited Sept. 29, 2012); see also THE World BANK, The Clean TeChNology Fund para. 30 (June 9, 2008), http://www.climate investmentfunds.org/cif/sites/climateinvestmentfunds.org/files/Clean_Technology_Fund_paper_June _9_final.pdf (noting other institutions with a mandate to promote investments in clean technology to address climate change could be invited to observe).

258. CTF Observers, supra note 257. For the purpose of observing meetings, the CIF defines Civil Society Organizations as "any independent non-profit organization of individuals working toward a common objective whose mandate is relevant to the purpose and objectives of the fund which is governed by the Trust Fund Committee or Sub-Committee for which observers are being selected.” CLIMATE INVESTMENT FundS, GUIDELINES FOR INVITING REPRESENTATIVES OF CIVIL SOCIETY to OBSERVE MeEtings of the CIF TRUST Fund COMmitTEES para. 5 (April 20, 2009), http://www.climateinvestmentfunds.org/cif/sites.climateinvestmentfunds.org/files/guidelines_for_ini nviti_reps_of_civil_society_to_cif_tfc_meetings_042009.pdf [hereinafter CIF GUIDELINES].

259. SCF Observers, supra note 257. CSO representatives here are required to reflect balance between status, gender, and geographic representation. CIF GUIDELINES, supra note 258, para. 7.

260. See Conference of the Parties Dec. 3/CP.17 Annex, Rep. of the Conference of the Parties, 17th Sess., Nov. 28-Dec. 11, 2011, U.N. Doc. FCCC/CP/2011/9/Add.1, I 16, at 60 (Mar. 15, 2012) (providing for civil society representation, as observers, in Green Climate Fund Board meetings). 
coequal decision-maker model for NGO participation. Like the GEF, the Fund has detailed mechanisms to assure the ongoing accountability and representativeness of the NGOs included.

This leap forward in the level of NGO involvement occurred because NGOs played a significant role in framing the Global Fund's governance structure from the outset. ${ }^{261}$ Research showed at the time that prevention and treatment of the Fund's target diseases were most likely to be effective with assistance from the local clinic level and not merely from the government. ${ }^{262}$ Accordingly, NGOs pressed the Fund's donors to channel resources to the grassroots level. ${ }^{263}$ The Global Fund's founders aimed to create an entity that had the capacity to enter into "robust collaborations with national and international partners" from both the public and private sector. ${ }^{264}$ The founders determined that the Fund should be able to work through local stakeholders rather than more traditional conduits such as UN agencies or other multilateral or bilateral development partners. ${ }^{265}$ They concluded that they could best meet these goals by establishing the Fund as a nonprofit foundation under Swiss law. ${ }^{266}$

The Global Fund has both a global-level and a country-level governance structure. Both structures reflect an unprecedented level of NGO participation. As the Fund's "supreme governing body," with

261. See Technical Support Secretariat, The Global Fund, NGOs and Civil Society CONSULTATION 1 (Oct. 8, 2001), http://www.theglobalfund.org/documents/board/twg/Board_TWG NGOConsultMeetingProposal_Report_en/ (noting the importance of involving "NGOs and Civil Society actors ... in the design of the Fund").

262. See, e.g., M.A. Mercer et al., The Role of Non-Governmental Organizations in the Global Response to AIDS, 3 AIDS CARE 265 (1991) (noting strengths of NGOs as compared to governments and recommending measures such as increasing NGO funding).

263. See The Global Fund to Fight AIDS, Tuberculosis and Malaria, Key RECOMMENDATIONS FROM THE NGO CONSUlTATION MEETING: BRUSSELS 12-13 NOVEMBER 2001, at 4 (2001), http://www.theglobalfund.org/documents/board/twg/Board_TWGNGO ConsultMeeting Recommendations_Report_en/ (stating that NGOs should have direct access to the Fund).

264. The Global Fund to Fight AIDS, Tuberculosis and Malaria, Report on Legal Status Options for the Global Fund, at 2, GF/B4/12 (Jan. 29-31, 2003), http://www.theglobalfund.org/documents/ board/04/BM04_12LegalStatusOptions_Report_en/.

265. See AlEXANDER SHAKOW, GLOBAL FUnd-WORLD BANK HIV/AIDS PROGRAMS: COMPARATIVE AdVANTAGE STUDY paras. 50, 71 (Jan. 19, 2006), http://www.cgdev.org/doc/event \%20docs/2.7.06\%20HIV/GFWBReportFinalVersion.pdf.

266. See Global Fund BY-LAWs, supra note 54, art. 1; see also The Global Fund to Fight AIDS, Malaria and Tuberculosis, Report Of The Governance and Partnership Committee, annex 6, at 3-6, GF/B5/7 (June 5-6, 2003), http://www.theglobalfund.org/documents/board/05/BM05_07 GPCReportAnnex6_Annex_en/ (noting the Global Fund's current status and discussing the advantages and disadvantages of other legal status options). As a nonprofit foundation, it operates under the supervision of the Swiss Federal Supervisory Board for Foundations. GLOBAL FUND BYLAWS, supra note 54 , art. 1. 
authority to set the Fund's policies and strategies, and allocate its resources, ${ }^{267}$ the Fund's Board of Directors is the Global Fund's locus of power at the global level. It plays a role similar to that of the GEF Council, including making final funding decisions. ${ }^{268}$ NGOs have the opportunity to play a substantial role in Board decision-making. The Board has a total of twenty-eight members, twenty of which are voting members. $^{269}$ Of the twenty voting Board members, three are NGO representatives, ${ }^{270}$ seven are representatives of developing countries, eight are representatives of donor countries, one is a representative of a private foundation, and one is a representative of the for-profit private sector. ${ }^{271}$ Every voting member of the Board has one vote. ${ }^{272}$

Like the GEF, the Global Fund mandates that the NGO representatives be diverse. ${ }^{273}$ Board members serve for two years or "such other term that the board may determine."274 The Fund's bylaws also ensure against the dilution of any constituency's voting power. Voting members are divided into two constituencies: one comprised of the donor and private representatives and the other comprised of

267. GLOBAL FUND BY-LAWS, supra note 54, art. 7.4.

268. See id. art. 7.4(iii). The Board also sets operational guidelines, work plans, and budgets for the Secretariat and the Technical Review Panel, and generally exercises all powers required to carry out the purposes of the Fund. See id. art. 7.4.

269. Id. art. 7.1.

270. The Global Fund's Framework Document refers to "civil society" in addition to using the term nongovernmental organization (NGO). See, e.g., GLOBAL FUnd FramewORK DocumENT, supra note 109, § VI (B)(1). As used in the Framework Document, however, the term "civil society" mirrors the term "NGO” as used in this Article. See Edwige Fortier, THE GLOBAL FUND TO Fights AIDS, Tuberculosis AND MALARIA, AN Evolving PARTNERSHIP: ThE GLOBAL Fund AND CIVIL SOCIETY IN THE FIGHT AGAINST AIDS, TUBERCULOSIS AND MALARIA 3 n.1 [hereinafter AN EVOLVING PARTNERSHIP], available at http://www.google.com (search "the global fund evolving partnership”) (last visited Oct. 19, 2012). The Global Fund uses the UN's definition of civil society. Id. According to that definition, civil society consists of "associations of citizens (outside their families, friends and businesses) entered into voluntarily to advance their interests, ideas and ideologies... not includ[ing] profit-making activity (the private sector) or governing (the public sector)." Id.

271. GLOBAL FUnD BY-LAWS, supra note 54, art. 7.1. The eight nonvoting members are comprised of the Board Chair and Vice-Chair, a representative from the World Health Organization, a representative from the Global Fund's trustee, the Global Fund's Executive Director, a representative from the Joint United Nations Programme on HIV/AIDS, a representative from the Partners constituency, and a Swiss citizen with "his or her domicile in Switzerland authorized to act on behalf of the Global Fund to the extent required by Swiss law." Id.

272. Id.

273. See id. (requiring that the Board NGO representatives include someone from a developing country, someone from a developed country, and someone living with AIDS or HIV or representing a community affected by TB or malaria).

274. Id. art. 7.2. 
developing country and NGO representatives. ${ }^{275}$ A two-thirds majority vote of each constituency is required to approve any matter put to a vote. ${ }^{276}$

At the country level, the Fund works through a local governance process known as the Country Coordinating Mechanism (CCM), which brings together within a single structure all actors working on AIDS, tuberculosis, and malaria within a given country. ${ }^{277}$ It includes representatives from government, multilateral and bilateral agencies, NGOs, and the private sector. ${ }^{278}$ NGOs' inclusion as part of the constituency groups gives them a substantial role in Global Fund decision-making at the country level. Each CCM must comprise at least $40 \%$ nongovernment constituencies, of which NGOs are a part. ${ }^{279}$ The CCM is the only entity in a given country that may submit a proposal for funding to the Global Fund. ${ }^{280}$

At both the global and country level, the Fund employs a sophisticated and stringent system for selecting the constituency representatives, including NGOs, which participate in its governance, and for ensuring their continued accountability. Each constituency group represented on the Board, including the five civil society representatives, is selected in accordance with processes agreed upon by their respective constituencies. ${ }^{281}$ The Fund sets guidelines for the processes constituencies should follow and what they should look for when selecting their Board members. ${ }^{282}$ At the country level, each CCM

\footnotetext{
275. Id. art. 7.6.

276. Id.

277. See GLOBAL Fund FrameWORK Document, supra note 109, § VI.

278. Id. § VI (B)(1).

279. The Global Fund to Fight Aids, Tuberculosis and Malaria, Guidelines and

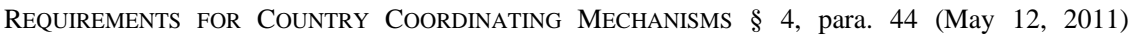
[hereinafter GUIDELINES FOR CCMs], available at http://www.theglobalfund.org/en/ccm/guidelines/.

280. Global Fund Framework Document, supra note 109, § VI (B)(6); see also Country Coordinating Mechanisms, GlOBAL FUND TO FIGHT AIDS, TUBERCULOSIS \& MALARIA, http://www.theglobalfund.org/en/ccm/ (last visited Sept. 30, 2012).

281. Global Fund BY-LAWS, supra note 54, art. 7.2. The processes are furnished to the Secretariat by the constituency group for reference. THE GLOBAL FUND TO FIGHT AIDS, Tuberculosis and Malaria, Operating Procedures of the BoARd and Committees $\S 5.2$ (Nov. 21, 2011), http://www.theglobalfund.org/documents/board/core/Board_GlobalFundBoard OperatingProcedures_en. The processes may require sector-wide consensus or accept a simple majority vote. See THE Global Fund to FIGHT AIDS, TUBERCULOSIS AND MALARIA, GUIDELINES ON CONSTITUENCY PROCESSES 5, http://www.theglobalfund.org/documents/publications/other/Pub lication_ConstituencyProcesses_Guidelines_en/ [hereinafter GUIDELINES ON CONSTITUENCY PROCESSES] (discussing three case studies where constituencies' Board members were selected different ways).

282. See GUIDELINES ON CONSTITUENCY Processes, supra note 281, at 3-5. For example,
} 
member representing NGOs is required to be selected by their constituency in a transparent selection process. ${ }^{283}$ CCMs must document their selection processes. ${ }^{284}$ They must make their selection criteria publicly available to the Global Fund and their constituency. ${ }^{285}$

In making its proposal to the Global Fund, the CCM nominates one or more entities known as "Principal Recipients" to implement the proposal. $^{286}$ The Global Fund enters into its grant agreements directly with the Principal Recipients who are the lead implementers of Global Fund grants and are directly responsible to the Fund for the financed program. ${ }^{287}$ The Principal Recipients may make sub-grants to a range of sub-recipients. ${ }^{288}$ Principal Recipients are often government ministries but NGOs, along with a range of other entities, are also eligible to serve in that role. ${ }^{289}$

No other entity has as yet replicated the Global Fund's processes for NGO inclusion. Recently, however, a global fund for primary school education in developing countries, the Education For All Fund, underwent a restructuring that included, inter alia, adopting a coequal decision-making model of NGO participation. ${ }^{290}$ The restructuring gives

Fund policies emphasize that a Board member should recognize that her participation is as a representative from a wider community, constituency, interest group or sector. See id. at 4 (noting the ability to act as an "ambassador/advocate" is key). Further, a member is expected to consult regularly with her constituency and to seek out feedback. See id. Fund Guidelines also provide that members of a constituency may select a member to serve as the Board representative for a full two years or implement an annual rotation system. Id. at 8.

283. The Global Fund to Fight AIDS, Tuberculosis and MALARIA, Guidance Note: CCM REQUIREMENTS req. 5 (June 2011), http://www.theglobalfund.org/documents/CCM/CCM_ RequirementsGuidance_Note_en/ [hereinafter GUIDANCE NOTE: CCM REQUIREMENTS].

284. Id

285. GUIDELINES FOR CCMs, supra note 279, § 4, para. 50.

286. The Global Fund to Fight AIDS, TubERCUlosis And MALARIA, Operational GUIDE: The Key tO Global Fund Policies AND Processes 15 (Aug. 2010), http://www.the globalfund.org/documents/core/guides/Core_GlobalFundPoliciesAndProcessesOperational_Guide_e $\mathrm{n} /$. The proposal is based on the CCM's review of proposals submitted to it from a diverse range of actors. See id. at 31 (noting that some CCMs issue calls for proposals and build a national proposal from there). It can consist of a request for funds to strengthen a country's health system. Id.

287. See Principal and Sub-Recipients, GLOBAL FUND TO FIGHT AIDS, TUBERCUlOSIS \& MALARIA, http://www.theglobalfund.org/en/about/structures/pr/ (last visited Sept. 30, 2012).

288. Id.

289. See An EVOlVING PARTNERShIP, supra note 270, fig. 4 (measuring the performance of three types of principal recipients including NGOs). The Fund contracts local in-country experts as Local Fund Agents to assess the capacity of proposed Principal Recipients to assume financial and program accountability for Fund grants. THE GLOBAL FUND TO FIGHT AIDS, TUBERCULOSIS AND MALARIA, FIDUCIARY ARRANGEMENTS FOR GRANT RECIPIENTS para. 11 (July 1, 2003), http://www. theglobalfund.org/documents/core/grants/Core_Fiduciary_Arrangements_en/. Further, once a grant has been disbursed, the Local Fund Agent provides ongoing oversight of accountability. Id.

290. EDUC. FOR ALL-FAST TRACK INITIATIVE, 2010 ANNUAL REPORT 20 (2011), http://www. 
education NGOs a voting role in the varying levels of the fund's decision-making bodies. ${ }^{291}$ The essential element of the coequal decision-maker model is undiluted NGO voting power.

\section{c. Critique of the Inclusion Norm}

Reviewing both models of the inclusion norm in the light of exclusionists' objections to NGO participation, we see that both forms overcome some of the civil society's skeptics' concerns about NGO participation in governance. ${ }^{292}$ The detailed policies and procedures the GEF and the Global Fund follow for selecting participating NGOs from large pools of eligible organizations tackle the problem of accountability. ${ }^{293}$ Both systems for rotating NGO representatives also allow for a continual monitoring of representatives' bona fides. The GEF-NGO Network's rule requiring active renewal of membership in the Network every three years provides an additional safeguard.

As Dana Brakman Reiser and Claire Kelly point out, the value of NGO participation in any institution depends in part on whether the institution monitors and enforces the accountability of NGO participants. $^{294}$ Such processes need to provide reassurance that participating NGOs are accountable entities when selected and remain such throughout their participation. Professors Brakman Reiser and Kelly note that national nonprofit regulatory regimes target three aspects of a nonprofit entity to regulate its overall accountability. ${ }^{295}$ These consist of the nonprofit's "mission, financial, and organizational accountability."296 Brakman Reiser and Kelly argue that the procedures international institutions employ in screening and selecting participating NGOs should include gatekeeping processes that incorporate these criteria. $^{297}$ The GEF and Global Fund's processes for selecting and

globalpartnership.org/media/misc/FastTrackInitiativeAnRptApr13.pdf.

291. See Civil Society Organizations, Global PARTNERSHIP FOR EDUC., http://www.global partnership.org/who-we-are/partners/cso-s/ (last modified June 18, 2012).

292. See supra Part III.B.1.

293. See Anderson \& Rieff, supra note 1, at 30 (noting that NGOs are not electoral institutions and can ignore citizens' will (citing Kenneth Anderson, The Limits of Pragmatism in American Foreign Policy: Unsolicited Advice to the Bush Administration on Relations with International Nongovernmental Organizations, 2 CHI. J. INT’L L. 371 (2001))).

294. See Brakman Reiser \& Kelly, supra note 33, at 1052.

295. See id. at 1029.

296. Id.

297. See id. at 1068 ("[Nonstate regulators] creating or revising their accreditation, monitoring, and enforcement mechanisms also should tailor them to complement domestic nonprofit regulatory 
monitoring NGOs offer a working example of how this recommendation may be realized.

These funds' gatekeeping processes also address concerns about conflicts of interest. These concerns arise when NGOs are eligible to submit proposals for funding to the institutions in whose governance they seek to participate. ${ }^{298}$ Conflict of interest concerns are more serious when NGOs vote on what gets funded. These concerns can be managed, however, when NGOs have to disclose their work programs and meet high standards of transparency. The funds' processes also show that concerns about numerosity are not insurmountable. Further, by implementing strict diversity criteria, and possessing the tools to achieve them, the funds enhance the likelihood that the NGOs that do participate will represent the communities the funds' assistance is directed at and thereby fulfill a key objective of NGO inclusion.

Both models of the inclusion norm, however, have their warts. Uncertainty lingers about how much active observers influence decisionmaking, ${ }^{299}$ and about what constituency active observers actually represent. ${ }^{300}$ Further, it is not clear what drives the limits funds impose, such as the exclusion of active observers from executive sessions of the GEF Council. These limits may be calculated decisions that the unique value-added of NGO participation-field-based and technical expertise-is not relevant to the subject matter of executive session meetings. Alternatively, the limits may be prompted by a parsimonious application of the old paymaster principle, which undermines the principle of inclusion.

It is difficult to conceive of a more extensive role for NGOs in institutional governance than the coequal decision-maker model, reflected in the multiple roles NGOs assume at every tier of the Global Fund's structure. The Global Fund's creators overcame both the ideologies and the concerns that ordinarily cause donors to balk at giving NGOs a meaningful vote. The model does, however, present concerns regarding capture. It is not clear that NGOs can simultaneously serve as

\footnotetext{
environments.”).

298. See id. at 1051 (noting how self-dealing can be an inherent problem in NGO participation).

299. See Climate Investment Funds, Review of the Self-Selection Process of Observers to CIF Committees and Effectiveness of Participation, annex 1, § II, CTF-SCF/TFC.5/7 (Oct. 28, 2010), available at http://www.climateinvestmentfunds.org/cif/node/2498 (noting that active observers to the CIF committees did not feel they could participate fully and freely).

300. Id. para. 17 (noting confusion on whether observers participated in an individual capacity, as a representative of an organization, or as a representative of the whole constituency).
} 
watchdogs, as the inclusionists note we need them to do, ${ }^{301}$ or as an effective "transnational civil society channel of accountability,"302 while being coequal decision-makers. Consequently, we are left to hope that there will always be others outside the decision-making circle to fill that need.

Notwithstanding the warts and some continued need for fine-tuning, both models of the inclusion norm pave the way for a very different framework for international development assistance than the exclusion norm. Ideally, the choices of which model of inclusion to use and what limits to apply will be governed by what is necessary to maximize the contribution of NGO participation. The very existence of both models, however, challenges the rationale for other institutions' continued adherence to the exclusion norm.

\section{The Exclusion Norm}

The level of NGO inclusion in the GEF, Global Fund, and now the Green Climate Fund, stands in marked contrast to the norm in older institutions. Despite the World Bank and UNDP's extensive rhetoric of inclusion, ${ }^{303}$ they both impose glass ceilings on NGOs' roles. Although significant changes in the direction of inclusion have occurred in these institutions since the 1990s, the push and pull of the inclusion-exclusion debate still favors exclusion at the governance level.

\section{a. Origin and Evolution}

In the case of UNDP, giving NGOs some voice was always a part of the UN's idea of itself, as provided for in Article 71 of the UN Charter. ${ }^{304}$ But the arrangements ECOSOC recommended to the UN General

\footnotetext{
301. See, e.g., Charnovitz, supra note 1, at 894 (stating that NGOs can "correct for the pathologies of ... [international organizations]").

302. Buchanan \& Keohane, supra note 62, at 432 (emphasis omitted).

303. See Civil Society: The World Bank and Civil Society, WORLD BANK, http://go.worldbank. org/ZEL7JBJM90 (last updated Sept. 25, 2012); UNDP Engagement with Civil Society, supra note 172.

304. See U.N. Charter, art. 71. As Steve Charnovitz points out, given the history of close government-nongovernment interaction in the UN's predecessor, the League of Nations, in which NGOs were engaged in many committees and conferences, Article 71's limitation to ECOSOC and consultation was not necessarily progress for NGOs. Charnovitz, supra note 48, at 250. Indeed, Charnovitz quotes one commentator as noting that Article 71 is a "so-far-and-no-further" provision. Id. (quoting Bertram PiCKARD, The GreAter United NATIONs 72 (1956)). NGOs actually assisted in the drafting of Article 71. Id. at 249.
} 
Assembly to implement Article 71 after the Charter went into force only touched on NGO participation in the form of consultation. ${ }^{305}$ ECOSOC confines NGOs to certain activities including attending ECOSOC conferences and making statements there, but it does not allow NGO participation in governance. $^{306}$ The World Bank, on the other hand, made no formal effort to secure NGO input in its work until the early 1980s and even then it only took baby steps. ${ }^{307}$ In 1981, it developed a policy for including NGO input in "all stages of project processingidentification, design, implementation, and monitoring and evaluation”308 and in 1984 it created an NGO-World Bank Committee to engage with NGO leaders. ${ }^{309}$

The attitude of the UN and the Bank toward NGOs changed following the fall of the Berlin Wall. The Cold War and the Westphalian system marginalized NGOs. ${ }^{310}$ Globalization, by contrast, centered them as key international actors. ${ }^{311}$ Faced with this soaring rise in the power and clout of NGOs, the UN and the Bank reached out to NGOs, partly actualizing what Professor Peter Spiro has dubbed the "paradox of inclusion." ${ }^{312}$

The UN's outreach to NGOs began in earnest with the 1992 UN Conference on Environment and Development (UNCED), ${ }^{313}$ which called on all UN agencies, including international development institutions, to "take measures to ... enhance existing or, where they do not exist, establish mechanisms and procedures within each agency to draw on the expertise and views of non-governmental organizations in policy and programme design, implementation, and evaluation....”314

305. See G.A. Res. 4(I), at 10, U.N. Doc. A/RES/4(I) (Feb. 14, 1946).

306. See The United NATIONS, Working With ECOSOC: AN NGOs Guide to CONSUltative STATUS 7 (2011), http://csonet.org/content/documents/Brochure.pdf (listing allowed activities for NGOs with consultative status).

307. See The World Bank, The Bank's Relations with NGOs: Issues and Directions, para. 13 (World Bank Social Development Papers, Paper No. 28, 1998), http://siteresources.worldbank.org/ INTRANETSOCIALDEVELOPMENT/Resources/SDP-28.pdf (noting the Bank's first policy note on NGOs was adopted in 1981).

308. WBGP 14.70, supra note 52, para. 1.

309. NELSON, supra note 162, at 56.

310. See Charnovitz, supra note 48, at 258 (noting that Cold War politics limited NGOs).

311. See Spiro, supra note 1, at 161 (“[G]lobalization ha[s] empowered NGOs.”).

312. See id. at 166-67 (arguing that including NGOs in institutional decision-making has the potential to limit their power because they would have to be more externally accountable and would have less incentive to criticize the institutions they participate in).

313. See Charnovitz, supra note 48, at 265.

314. Id. (alterations in original) (quoting Agenda 21: The United NATIONS PROgramme of ACTION FROM RIO, para. 27.9, U.N. Doc. A/CONF. 151/26/Rev. 1, U.N. Sales No. E.93.I.11 (1992); 
Responding to this call, ECOSOC passed a resolution creating an updated framework for NGO accreditation. ${ }^{315}$ Under the new framework, NGOs may secure accredited status to: (1) observe and potentially speak at public ECOSOC meetings, (2) propose items for provisional agendas, and (3) submit statements. ${ }^{316}$

This increased outreach to NGOs continued into the new millennium but within clear constraints. The Secretary-General appointed a Panel of Eminent Persons on United Nations-Civil Society Relations in 2003 and gave it a broad mandate to examine the appropriate role of civil society in the UN. ${ }^{317}$ The Panel affirmed that greater NGO participation would strengthen the UN as an institution. ${ }^{318}$ It did not, however, suggest

see also KARNS \& MINGST, supra note 48, at 466-68 (discussing the conference and its outcomes).

315. Charnovitz, supra note 48, at 266-67 (citing E.S.C. Res. 1996/31, U.N. Doc. E/RES/1996/31 (July 25, 1996)).

316. Id. at 267 (citing E.S.C. Res. 1996/31, supra note 315, paras. 27-32). Under the ECOSOC resolution, NGOs may secure varying levels of accreditation status with ECOSOC and its subsidiary bodies, depending on how relevant their work is to ECOSOC or the particular subsidiary body. See id. Briefly, the ECOSOC arrangements divide NGOs into three categories: category I, "General" status; category II, "Special” status; and category III, "Roster" status. Id. Category I is comprised of "[l]arge, multifaceted international NGOs.” KARNS \& MINGST, supra note 48, at 232 fig. 6.3. Category II is comprised of "[i]nternationally known NGOs who enjoy expertise in a particular issue area." Id. Category III is made up of "[s]maller NGOs, with occasional interests in ECOSOC activities.” Id.

Category I NGOs have the most expansive input once they are accredited, and have the opportunity to "consult with officers from the [Council] Secretariat on matters of interest to the NGO," proposing items for agendas, and speaking at "ECOSOC and functional commission meetings.” Id. NGOs internationally known for a particular area of expertise relevant to ECOSOC's work have similar rights with respect to addressing matters within their expertise. See id. Smaller NGOs, on the other hand, have less access. See id. For example, their representatives cannot address ECOSOC meetings. See id. The updated framework also established that "national, regional, and sub-regional NGOs may seek consultative status," which had not been the case before. Charnovitz, supra note 48, at 267 (citing E.S.C. Res. 1996/31, supra note 315, para. 4). It also set a goal of genuine and effective engagement of NGOs from all regions of the world. Id. (quoting E.S.C. Res. 1996/31, supra note 315, para. 5).

317. See UN-NGO Relations, UN NON-GOVERNMENTAL LiaISON SERVICE, http://www.unngls.org/orf/ngorelations.htm (last visited Oct. 1, 2012).

318. See U.N. Secretary-General, We the Peoples: Civil Society, the United Nations and Global Governance: Rep. of the Panel of Eminent Persons on United Nations-Civil Society Relations, para. 27, U.N. Doc. A/58/817 (June 11, 2004) [hereinafter We the Peoples] stating that "enhanced engagement [with civil society] will make the United Nations more effective"). Enhanced UNNGO engagement, the report urged, "could help the United Nations do a better job, further its global goals, become more attuned and responsive to citizens' concerns and enlist greater public support." Id. Executive Summary, at 8 . The Panel's specific recommendations include permitting the participation of actors outside of central governments in the General Assembly's processes, id. at 37, strengthened dialogue between the civil society organizations and the Security Council, id. at 46, and improvements in the process for accrediting civil society organizations. Id. at 56. Regarding the latter, the Report stated that the process should be depoliticized and handled by a central UN Accreditation Unit. Id. paras. 127, 131. Further, the process needs to address concerns that NGOs sponsored and controlled by governments are being accredited and that the process would result in a 
changing the UN's essential character as an exclusively intergovernmental organization. The Panel stopped short of recommending formal NGO access to the UN General Assembly, as some had suggested. ${ }^{319}$ Instead, the Panel's recommendations aimed broadly at reinvigorating that intergovernmental process by "[e]mbracing a plurality [of] constituencies," actors, and partnerships. ${ }^{320}$

UNDP has similar restrictions on NGO participation. UNDP created an institutionalized forum for UNDP-NGO dialogue in the form of the UNDP CSO (Civil Society Organizations) Advisory Committee, which operates at the global level, and similar committees to operate at the country level. ${ }^{321}$ Following ECOSOC's approach, however, UNDP excludes NGOs from participating in the decision-making of UNDP's Executive Board. ${ }^{322}$

After the World Bank established the World Bank Inspection Panel in 1993, it formalized a more active approach to NGO involvement in the Bank's affairs. It created formal bodies responsible for initiating and maintaining dialogue with NGOs at the central, regional, and country level to allow for systemic engagement. ${ }^{323}$ In principle, the Bank now

North-South representation imbalance. Id. paras. 127, 161-63. To alleviate this concern, the Report urged the UN to provide financial support for civil society in the poorer developing countries. Id. para. 165. Finally, the Report stated that the UN should urge member governments to allow civil society to flourish at the national level. Id. para. 175. "Effective engagement with civil society ... is no longer an option - it is a necessity ...." Id. para. 38.

319. The Conference of Non-Governmental Organisations in Consultative Status with the United Nations Economic and Social Council (CONGO), for example, has lobbied for NGOs to have formal access to the General Assembly and for standardized procedures for NGO access to UN conferences. KARNS \& MINGST, supra note 48, at 231. NGOs have not, however, "been united in [the] push to expand participation.” Id. at 233. Some major international NGOs view themselves as a privileged elite and "worry about their influence being diluted by an influx of thousands of new grassroots NGOs.” Id.

In some limited cases, however, NGO engagement expands into the activities of the Security Council. See id. Following various consultations between NGOs and the Council on specific issues, the Council formed an NGO Working Group on the Security Council, with which the Security Council president meets periodically, privately, and off the record. Id. at 233.

320. We the Peoples, supra note 318, Executive Summary, at 9.

321. UNDP Engagement with Civil Society, supra note 172; see also UNDP ENGAGEMENT NoTE, supra note 172, paras. 18-19 (lauding the establishment of the Advisory Committee and noting the need for analogues at different levels). In addition to relying on NGOs to carry forward its policy goals through advocacy campaigns, UNDP contracts directly with NGOs to execute UNDP-funded programs. Id. paras. 37, 39.

322. See Members of the Executive Board, United Nations Dev. Programme, http://www. undp.org/content/undp/en/home/operations/executive_board/membership (last visited Oct. 1, 2012) (showing that all members of the Executive Board are representatives of nations).

323. See WBGP 14.70, supra note 52, para. 12 (noting the "NGO-World Bank Committee meets regularly on both a global and regional basis to discuss issues of mutual concern" and that country offices also systematically interact with NGOs). At the country level, many Bank Country Offices 
gives credence to a role for NGOs in both its inputs and outputs. For example, around 600 NGOs attended the Bank's 2011 annual meetings, ${ }^{324}$ including well-known organizations like World Vision, Oxfam, Actionaid, and Transparency International, along with numerous medium-sized and smaller local groups. ${ }^{325}$ Further, a diverse cross section of NGOs participated in recent Bank consultative meetings on the role of NGOs at the Bank, among them TrustAfrica (Senegal), Partnership for Transparency Fund (India), and the Centre for Democratic Development (Ghana). ${ }^{326}$

Outwardly, the Bank extols the benefits NGOs bring to the intelligence function, noting that NGO strengths commonly include "social proximity (grassroots and community links);... field-based development expertise; [and] important specialized knowledge or skills." 327 The Bank also acknowledges the importance of NGOs' advocacy role in offering grassroots insights and in challenging conventional development thinking. ${ }^{328}$ Further, the Bank encourages NGOs to exercise a prescriptive role. When formulating policies, strategies, and procedures, and when writing major reports, Bank staff seek input from expert NGOs. ${ }^{329}$ NGOs also monitor and evaluate Bank projects and are "particularly effective in monitoring project impacts on indigenous people and the environment." ${ }^{330}$ Additionally, NGOs may be engaged in implementing projects ${ }^{331}$ and a number of Bank grant programs include NGOs as eligible recipients. ${ }^{332}$

\footnotetext{
have a dedicated NGO Specialist or Liaison Officer who "establishes and maintains effective relations among the Bank, the borrower, and NGOs at the country level." Id. para. 30. At the regional and network levels, the "NGO-Civil Society Unit of the Social Development Family develops and coordinates the Bank's overall relationship with NGOs.” Id. para. 31. This unit "promotes within the Bank practices and procedures that facilitate collaboration with NGOs" and "monitors NGO involvement in Bank-financed activities." Id.

324. Civil Society: Mainstreaming CSO Participation in the Annual Meetings, WORLD BANK, http://go.worldbank.org/XO68BPDNP0 (last updated Oct. 27, 2011).

325. See The World Bank, List of CSO Representatives Present at the 2011 Annual Meetings, http://siteresources.worldbank.org/CSO/Resources/2011AMs-ARRIVED-CSOs-List-FINAL.pdf.

326. See, e.g., The World Bank, List of Participants: Roundtable-Supporting the Accountability Agenda: The Enhanced Role of CSOs, http://siteresources.worldbank.org/CSO/Resources/cons_april 27_participant.pdf.

327. WBGP 14.70, supra note 52, para. 6(a)-(c)

328. Id. para. 7.

329. Id. para. 11.

330. Id. para. 22.

331. Id. para. 13.

332. Id. para. 23. For a full account of World Bank grant programs, see Smyth, supra note 171.
} 
But the Bank does not reinforce its repeated acknowledgement of NGOs' potential contributions with a strong commitment to engaging with NGOs. ${ }^{333}$ The Bank encourages its staff to consult with NGOs at various levels of its work. ${ }^{334}$ It also gently encourages its borrowers to involve NGOs. ${ }^{335}$ In neither case, however, does it back its exhortations with incentives. For example, although the Bank acknowledges NGOs' expertise on indigenous peoples, ${ }^{336}$ it does not include NGO representatives of indigenous peoples-whose livelihoods will be directly affected-in formulating conditions of Bank loans intended to protect indigenous people. $^{337}$

Accordingly, the Bank's external political climate, rather than its institutional commitment, is its incentive to seek NGO inputs. In some instances, this external pressure may suffice. After all, the Bank's external operating environment is characterized by a history of vociferous protests by anti-globalization protesters and others against certain Bank actions. ${ }^{338}$ But, merely exhorting consultation stops far short of affording NGOs a meaningful role in the institution, or a voice before the Board of Executive Directors, the seat of the Bank's power.

\section{b. Critique of the Exclusion Norm}

The UN, acting through UNDP, and the World Bank say that NGO participation is essential to their institutional credibility. Both institutions frame that assertion as a belief that NGO participation contributes to their institutional effectiveness. At odds with this position, however, is their lack of substantive action to ensure that NGO input will be secured and heard. The World Bank and UNDP's decision-making

333. See WBGP 14.70, supra note 52, para. 1 (encouraging but not mandating collaboration with NGOs).

334. See id. (stating that the Bank "encourages borrowers and staff members to consult with NGOs and to involve them, as appropriate, in Bank-supported activities, including economic and sector work and all stages of project processing -identification, design, implementation, and monitoring and evaluation”).

335. See id. para. 17.

336. See id. para. 22

337. See Woods, Intergovernmental Institutions, supra note 129, at 70 (noting that "there are increasing calls for particular groups within countries whose livelihoods are affected by the [Bank] to be included directly in the formulation and implementation of conditionality").

338. See, e.g., Stiglitz, supra note 2, at 3; Anup Shah, IMF \& World Bank Protests, Washington, D.C., GLOBAL ISSUES, http://www.globalissues.org/article/23/imf--world-bankprotests-washington-dc (last updated July 13, 2001) (describing protests against the Bank in April 2000) 
bodies remain the preserve of a constricted, state-only club. Further, absent the imposition of mandatory requirements on Bank staff to obtain and reflect NGO input in the proposals they present to the Board, the information and inputs on which that club bases its decision will likely continue to be constricted also.

Neither inclusion nor exclusion need be absolute. A closer look at the kinds of decisions the Board makes shows why a more nuanced approach would make sense. Recall that the founders of the Bank were concerned not to give the institution a blank check to lend. ${ }^{339}$ That is why the founders detailed specific conservative financial policies in the Bank's Articles of Agreement. The founders of such institutions, therefore, would need to consider the specific aspects of institutional decision-making with which NGO input would be helpful. For example, the Bank depends on bonds it sells on capital markets for its operating capital. $^{340}$ The viability of that financing model, therefore, cannot be jeopardized. The expertise and experience of development-focused NGOs is not relevant to the Bank's decisions about what bond markets to tap and what rate of interest to pay. On the other hand, the input of NGOs may be highly relevant, possibly invaluable, to decisions about how to design a loan to defray the costs of adjusting a country's tax base or installing a new sewer system. To properly calibrate where NGO participation could make a contribution, however, the norm of exclusion would first have to shift.

Despite the newer institutions' embrace of NGO participation in governance, it would be a mistake to assume that we are on a forward march towards an inclusion norm. True, given the strength of NGOs in the Western Hemisphere, it is difficult to imagine that an international development institution created by Western powers today would completely exclude NGOs from participation. Western powers, however, are not the only donors to international development institutions. Indeed, their influence is poised to decline as emerging powers become increasingly engaged in international development assistance. $^{341}$ For example, changing power dynamics in the World Bank-which give a stronger voice to emerging economies ${ }^{342}$ that have

\footnotetext{
339. See supra notes $113-18$ and accompanying text.

340. See supra note 118 and accompanying text.

341. See Ngaire Woods, Whose Aid? Whose Influence? China, Emerging Donors and the Silent Revolution in Development Assistance, 84 INT'L AFF. 1205, 1205-06 (2008) (noting the existence of emerging donors and their challenge to the current development regime).

342. See Leslie Wroughton, China Gains Clout in World Bank Vote Shift, ReUTERs (Apr. 25,
} 
traditionally been hostile to NGOs (notably China) ${ }^{343}$ —make it possible that the exclusionist view will emerge with new vigor. Notably, in the single example of a special purpose fund where developing countries have a controlling voice over Western democracies, namely the Adaptation Fund, the degree of NGO participation in governance is nugatory. $^{344}$

Additionally, a significant segment of other nonstate actors, the forprofit arm of the private sector (courted by both established institutions and special purpose funds), ${ }^{345}$ tend to disfavor NGO participation. ${ }^{346}$

2010), http://reuters.com/article/2010/04/25/us-worldbank-idUSTRE63O1RQ20100425 (noting the increase to $4.42 \%$ from $2.77 \%$ in China's share of voting power as part of a shift at the World Bank to give emerging economies more influence).

343. See Deyong Yin, China's Attitude Toward Foreign NGOs, 8 WASH. U. GLOBAL STUD. L. REV. 521, 529-30 (2009) (noting that NGOs concerned with politically sensitive issues risk "abrupt closure” in China but also that Chinese officials have become less negative towards foreign NGOs).

344. See The Adaptation Fund NGO Network-How it Works ..., ADAPTATION FUND NGO NETWORK, http://germanwatch.org/klima/afn1.htm (last visited Oct. 2, 2012) (detailing actions NGOs can take related to the Adaptation Fund's board, including observation of board meetings and exchanges with board members). The Adaptation Fund is one of the funding mechanisms of the Kyoto Protocol to the UNFCCC. Ralph Czarnecki \& Kaveh Guilanpour, The Adaptation Fund After Poznán, 2009 CARBon \& Climate L. REV. 79, 79 (2009). It became operational in late 2008-early 2009. See id. The Fund is financed from the sale of certified emission reductions (CER) credits. About the Adaptation Fund, ADAPTATION FUND, http://www.adaptation-fund.org/about (last visited Oct. 2, 2012). CER credits are issued for “emission-reduction projects in developing countries." Id. Developed countries can sell CER credits to help them reach their targets for emission reduction under the Kyoto Protocol. Id. The Adaptation Fund is controlled by the Adaptation Fund Board (AFB). Id. The design of the AFB purposefully gives developing country representatives majority control. See Adaptation Fund Board, ADAPTATION FUnD, http://www.adaptationfund.org/about/the-board (last visited Oct. 2, 2012) (noting 69\% of AFB members are representatives of developing countries). Of the sixteen-member board, ten positions are selected from the five UN regional groupings, two per group. Id. In all of these regions, except for the Western European and Others region, developing countries dominate the membership. See United Nations Regional Groups of Member States, DeP’T Gen. Assembly \& Conf. MgMT., http://www.un.org/Depts/DGACM/RegionalGroups.shtml (last updated Sept. 10, 2012). In addition, of the remaining six board seats, four positions are guaranteed to non-Annex I countries of the UNFCCC (all of which are developing countries), see List of Non-Annex I Parties to the Convention, UNiTED NATIONS FRAMEWORK CONVENTION ON CLIMATE CHANGE, http://unfccc.int/parties_and_ observers/parties/non_annex_i/items/2833.php (last visited Oct. 2, 2012), by reserving one seat for a small island developing country, one for a representative of the least developed countries, and two more for other non-Annex I countries. Adaptation Fund Board, supra. AFB voting is strictly one vote per board member-there is no weighted voting system. THE ADAPTATION FUND, RULES OF Procedure of THE ADAPTATION FUND BOARD para. 45. NGOs can participate in the AFB meetings as informal observers and informal consultants, but they have no formal space in the fund's design. See id. paras. 31-34.

345. See, e.g., Smyth, supra note 37, at 1000 (noting that the Global Fund's creators thought "contributions and participation of the private sector ... to be of vital importance to the Fund's success” (citing FIRST MEETING OF THE TRANSITIONAL WORKING GROUP TO ESTABLISH A GLOBAL FUND TO FIGHT AIDS, TUBERCULOSIS AND MALARIA 5 (2001), available at http://theglobalfund. org/documents/board/twg/Board_1STTWG_Report_en/)).

346. See Crocker Snow, Jr., NGO Overreach: Greenpeace Pours Oil on Troubled Waters but 
This tendency is apparent in a family of special purpose funds that "purchase project-based greenhouse gas emission reductions in developing countries," called the World Bank Carbon Finance Unit. ${ }^{347}$ The Carbon Funds in the Carbon Finance Unit are comprised of forprofit and government donors and provide no space for NGOs in their governance structures. ${ }^{348}$ The exclusionist norm, therefore, is far from dead.

\section{NGOs' Contribution to Credibility}

What, then, does the contrast between the role of NGOs in the special purpose funds and the established institutions indicate for the importance of NGO participation in governance to the credibility of international development institutions? Fundamentally, the contrast is a testament to a major change in the power dynamics of international development assistance since the end of the Cold War. The special purpose funds' growth in popularity epitomizes the growth of NGO power and influence. Throughout the Cold War, and before it, international development assistance was largely a government-togovernment affair. ${ }^{349}$ The primary concern of the world powers that control international development institutions like the World Bank was to have those institutions do whatever was necessary and within their power to preserve Cold War allegiances. ${ }^{350}$ Supporting those allegiances, not achieving development, was the primary goal of international development assistance. ${ }^{351}$ Little attention was paid to what inputs these institutions should rely on in deciding what activities to fund. ${ }^{352}$ Indeed, these institutions acted unquestioningly as governmentonly clubs.

Can't Clean it Up, FletCher F. World AfF., Summer/Fall 1997, at 161, 162 (discussing how NGOs can attack corporations and “revel in raising questions about [corporations'] accountability”). But see Spiro, supra note 194, at 968 (noting corporations may welcome NGO participation because NGOs would then be forced to become more accountable).

347. About World Bank Carbon Finance Unit (CFU), CARBON FIN. UNIT, WORLD BANK, http://wbcarbonfinance.org/Router.cfm?Page=About\&ItemID=24668 (last visited Oct. 2, 2012).

348. See Carbon Finance at the World Bank: List of Funds, CARBON FIN. UNIT, WORLD BANK, http://wbcarbonfinance.org/Router.cfm?Page=Funds\&ItemID=24670 (last visited Oct. 2, 2012).

349. See Smyth, supra note 171, at 498.

350. See WooDs, supra note 60, at 33 (noting that the World Bank's “work became inextricably linked to the geopolitical imperatives of the Cold War”).

351. See, e.g., id. at 33-34 (discussing Bank patterns of support and noting that "U.S. administrators were required by law to ensure that any assistance to which they contributed met U.S. geopolitical needs”).

352. See id. at 39 (stating that history, economic theory, and their organizational charters did not 
That status quo has changed. The transboundary expansion of cause NGOs has been unleashed, and their concerns have now replaced donor countries' Cold War preoccupations as the driving force in setting international development aid agendas. ${ }^{353}$ Countries' foreign affairs agendas still influence development assistance, but the rise in NGO power coupled with the emergence of global problems has changed both the key priorities and the key actors involved. The growth of the special purpose funds, and the role NGOs play in them, is the result of these changes. The funds' structures indicate that the driving forces behind international development assistance have changed. NGOs dominate the agenda. That change begs the question of who should be involved in a development institution's decision-making. The incremental, but persistent and ongoing, increase in NGO participation in the special purpose funds shows that the case for NGO participation is irrefutable in the face of political realities.

This dynamic is evident in NGOs' expanding role in GEF governance, in their role as coequal decision-makers in the Global Fund, and in the starting assumptions in the framing of the Green Climate Fund. ${ }^{354}$ At no point, for example, was the exclusion of NGOs from fund governance contemplated for the Green Climate Fund. The only question put before the Working Group responsible for the Green Climate Fund's design was which of the two competing models, active observer or coequal decision-maker, the Green Climate Fund would adopt. $^{355}$ The interesting question is whether those realities will also force greater NGO participation in the older institutions. Donor states may continue to create and finance multiple new institutions for multiple new needs. Alternatively, donors may reconfigure the World Bank and the UN so they serve the central role in international development they were originally created to serve. Recapturing these institutions' credibility will take more than providing for NGO participation in governance. ${ }^{356}$ In our multi-stakeholder international order, however, opening a role for NGOs in governance would be one necessary step.

help define to whom the World Bank and IMF should lend or under what conditions).

353. See supra note 3 and accompanying text.

354. See supra Part III.B.

355. See Press Release, Framework Convention on Climate Change-Secretariat, Design Process of UNFCCC Green Climate Fund Fully on Track, Says UNFCCC Executive Secretary (Sept. 13, 2011) (noting the Fund's creators participated in a workshop on, inter alia, how to engage civil society in the Fund).

356. See generally Pincus \& Winters, supra note 19 (discussing the numerous criticisms of the World Bank and proposed solutions). 
In the absence of empirical research, we do not know whether NGO participation in governance actually improves a development institution's effectiveness. Functionally, however, the special purpose funds clearly have some lessons to impart. They illustrate the minimum conditions necessary to maximize the likelihood that NGO participation in governance will have a positive impact on institutional credibility. Three guideposts stand out in particular.

First, the special purpose funds show that to be meaningful, NGO participation must occur at an institution's locus of power. NGOs must have access to the body that both sets policy and decides what projects and activities the institution will finance among competing proposals. Further, as the GEF experience shows, there should be flexibility in when and where NGO participation is allowed. This flexibility allows for the possibility that the power center of an initiative may change over time-as happened, for example, in the infiltration of significant policy discussions into GEF replenishment meetings. ${ }^{357}$

Second, the special purpose funds show that the decision to create a space for NGOs is just a first step. It must be accompanied by further decisions on processes and mechanisms. These must address procedures for selecting the NGOs that will participate and for continually monitoring the accountability of NGOs after they are selected. These processes keep potential conflicts of interest in check. Further, processes are necessary to guard against NGOs' inputs being tainted by their interest in obtaining an implementing role in a given project or proposal.

Both the GEF and the Global Fund provide clear indicators of what those processes and mechanisms should contain. The GEF's amendment of its processes on this issue, for example, shows that the NGO community itself is best suited to select and monitor the NGO representatives. Fund donors, however, play a key role upfront in setting the parameters for selection, particularly by mandating diversity and a reasonable balance of international and local NGO representatives.

Third, the special purpose funds show that for NGO participation to have meaningful potential to enhance credibility, NGOs' access to formal meetings as observers must be supplemented by opportunities for pre-meeting meetings, along with some level of continual engagement at the country or regional level. The intra-meeting connections forged by the GEF-NGO Network, for example, have been a key part of the NGOs'

357. See Smyth, supra note 119, at 86-87. 
participation in the GEF. ${ }^{358}$ The NGO universe is vast and inchoate, making some level of mandated continual engagement critical to NGO participation being truly representative.

\section{CONCLUSION}

NGO participation in the governance of international development institutions is not critical to those institutions' legitimacy unless member governments expressly mandate such participation. International development institutions will be legitimate regardless of whether they include NGOs in governance as long as they comply with the predetermined mandates of the states that create them. Recent evidence suggests, however, that NGO participation in governance may be critical to an international development institution's credibility. NGOs have become key drivers and mobilizers of public support for international development assistance, and experience shows that their support is contingent on their having a role in governance.

NGOs' expanded role as a driving force behind international development has led to donor states setting up a host of special purpose funds, which serve as alternatives to the World Bank and the UN. This phenomenon shows that the older institutions have lost ground as the fulcrum of international development assistance. This result suggests that the older institutions' continued exclusion of NGOs from governance may come at an unsustainable cost to their institutional credibility and their relevance to the development challenges of the future. If member states want the Bank and UNDP to be at the center of the action, they will need to reconsider their exclusion of NGOs from those institutions' governance. They will need to realign their rhetoric acknowledging NGOs' unique expertise with their practices by allowing that expertise to be heard and absorbed at the level of institutional governance. The future face of international development assistance hangs in the balance.

358. See supra Part III.B.1.a. 